\title{
Analysis of the Physicochemical, Mechanical, and Electrochemical Parameters and Their Impact on the Internal and External SCC of Carbon Steel Pipelines
}

\author{
Luis Manuel Quej-Ake ${ }^{1, *}$, Jesús Noé Rivera-Olvera ${ }^{2}$, Yureel del Rosario Domínguez-Aguilar ${ }^{1}$, \\ Itzel Ariadna Avelino-Jiménez ${ }^{1}$, Vicente Garibay-Febles ${ }^{1}\left[\right.$ and Icoquih Zapata-Peñasco ${ }^{1, *}$ (D) \\ 1 Instituto Mexicano del Petróleo, Eje Central Lázaro Cárdenas Norte 152, San Bartolo Atepehuacan, \\ Alcaldía Gustavo A. Madero, Ciudad de México C.P.07730, Mexico; yureelrda@gmail.com (Y.d.R.D.-A.); \\ iaavelino@imp.mx (I.A.A.-J.); vgaribay@imp.mx (V.G.-F.) \\ 2 Tecnológico Nacional de México, Campus Ixtapaluca, TESI, Km. 7 de la Carretera Ixtapaluca-Coatepec s/n, \\ Ixtapaluca, Estado de México C.P.56580, Mexico; jnoe.rivera@tesi.edu.mx \\ * Correspondence: lquej@imp.mx (L.M.Q.-A.); izapata@imp.mx (I.Z.-P.)
}

Received: 23 November 2020; Accepted: 15 December 2020; Published: 17 December 2020

check for updates

\begin{abstract}
The review presented herein is regarding the stress corrosion cracking (SCC) phenomena of carbon steel pipelines affected by the corrosive electrolytes that comes from external (E) and internal (I) environments, as well as the susceptibility and tensile stress on the SCC. Some useful tools are presented including essential aspects for determining and describing the E-SCC and I-SCC in oil and gas pipelines. Therefore, this study aims to present a comprehensive and critical review of a brief experimental summary, and a comparison of physicochemical, mechanical, and electrochemical data affecting external and internal SCC in carbon steel pipelines exposed to corrosive media have been conducted. The SCC, hydrogen-induced cracking (HIC), hydrogen embrittlement, and sulfide stress cracking (SSC) are attributed to the $\mathrm{pH}$, and to hydrogen becoming more corrosive by combining external and internal sources promoting cracking, such as sulfide compounds, acidic soils, acidic atmospheric compounds, hydrochloric acid, sulfuric acid, sodium hydroxide, organic acids (acetic acid, mainly), bacteria induced corrosion, cathodic polarization, among others. SCC growth is a reaction between the microstructural, chemical, and mechanical effects and it depends on the external and internal environmental sources promoting unpredictable cracks and fractures. In some cases, E-SCC could be initiated by hydrogen that comes from the over-voltage during the cathodic protection processes. I-SCC could be activated by over-operating pressure and temperature at flowing media during the production, gathering, storage and transportation of wet hydrocarbons through pipelines. The mechanical properties related to I-SCC were higher in comparison with those reviewed by E-SCC, suggesting that pipelines suffer more susceptibility to I-SCC. When a pipeline is designed, the internal fluid being transported (changes of environments) and the external environment concerning SCC should be considered. This review offers a good starting point for newcomers into the field, it is written as a tutorial, and covers a large number of basic standards in the area.
\end{abstract}

Keywords: stress corrosion cracking (SCC); external-SCC; internal-SCC; pipeline steel

\section{Introduction}

In upstream and downstream oil and gas industries two major problems are found during operating pipeline system transporting hydrocarbons that are related to external and internal corrosion damage, where corrosion surfaces are fundamentally caused by water containing aggressive ions 
as the dominant parameter. It is not surprising that a mechanical failure could be started by water solution as well [1-3]. It can become somewhat significant when the change of strain, shape, and damage are not subjected to control by the external or internal applied force on pipelines. The external and internal corrosion processes have negative effects which in turn both generalized (uniform) and localized corrosion damage could be attributed to stress corrosion cracking (SCC) [4-13]. They could spread in a wide range of systems from the pipeline walls. Common solutions to this are cathodic protection, coatings, and chemical treatment applications. The negative effects of the phenomena of external SCC on carbon steel pipelines could be influenced by the hydrogen generated during cathodic protection, prepared soil solutions, carbonates and bicarbonate solutions as well as the hydrogen that originate from the sulfide compounds, HIC from acidic soils, acidic atmospheric compounds, organic acids, external bacteria induced corrosion, among other external solution promoting cracking [14-24]. Oxygen and hydrogen that comes from the low and high (overprotection) cathodic protection, respectively, becoming negative effects for external SCC $[25,26]$. Negative effects required for the occurrence of internal SCC are attributed to aggressive gas and $\mathrm{pH}$ that comes from oilfield produced water, sour media or brine sour media (hydrogen sulfide compounds, bisulfide compounds, and carbon dioxide), sulfuric acid, naphthenic acids, hydrochloric acid, organic acids (acetic acid, mainly), sodium hydroxide, internal bacteria induced corrosion, cathodic polarization, over-operating pressure, elevated temperatures, among other data of internal environment promoting cracking [13,27-32]. Others are related to the incorrect inhibitor types complimented with an inappropriate operating pressure where a low inhibition efficiency could be achieved $[13,33]$. As a result, other special forms of external and internal corrosion such as hydrogen blistering, hydrogen embrittlement, intergranular corrosion, pitting corrosion, microbiological corrosion (aerobic or anaerobic), corrosion under deposits, cell concentrations, galvanic corrosion near to weld, erosion, coating failures, among other mechanisms can be identified [34-39]. This is because the carbon steel containing high concentration of iron tends to return to the native ores in the form of oxide or hydroxide compounds (native compounds) after its refining process in a blast furnace. It is important to mention that the pipelines are usually designed, constructed and installed in consideration of the factors of the external and internal environments that they are exposed to, including metallurgy and stresses (including residual, applied, and criteria safety factors) [40,41]. However, the SCC growth is a type of unpredictable corrosion damage where a static tensile and constant load (mechanical effects) for pipelines exposed to corrosive environments is applied [1,42]. Consequently, the original mechanical properties of the carbon steel pipelines may be modified (displaced) toward high susceptibility to SSC (poor mechanical properties), where the crack and fracture starts [11]. Then, cracks propagate within deformations to achieve a total failure, and this should be tested at laboratory level (experimental scenarios before and after electrochemical evaluations) by combining electrochemical and mechanical measurements [43,44]. For that reason, the range of variables studied and reported in the literature is especially important. In the present work, a brief review regarding the SCC phenomena data is discussed. Then the corrosive electrolytes and other parameters reported in the literature regarding the external and internal SCC of carbon steel pipelines based on physicochemical, mechanical, and electrochemical data are highlighted. An experimental review, a brief experimental summary, and a comparison for physicochemical, mechanical and electrochemical data affecting external and internal SCC for carbon steels exposed to external and internal corrosive media were carried out.

\section{A Review of the SCC Phenomena}

Stress corrosion cracking (SCC) is a phenomenon by which a material cracks because of the action of a corrosive media and tensile stresses into the material. External-stress corrosion cracking (E-SCC) is a cause of failure in buried pipelines transporting hydrocarbons and its derivatives where the oxides start from the outside diameter (OD) of the pipeline. The external protective coating can suffer damage, and a wet environment may be generated between the coating and pipeline surface as a function of time, and this environment may induce the development of E-SCC degrading it. Internal stress 
corrosion cracking (I-SCC) in pipelines may be produced by internal fluid that contain different partial pressure of acid sulfide $\left(\mathrm{H}_{2} \mathrm{~S}\right)$, carbon dioxide $\left(\mathrm{CO}_{2}\right)$, carbonic acid $\left(\mathrm{H}_{2} \mathrm{CO}_{3}\right)$, naphthenic acid, oxygen, and water $\left(\mathrm{H}_{2} \mathrm{O}\right)$. The corrosion problem described before is increased by the minimum or maximum operating pressure and temperature. E-SCC can be found on gas pipeline more than in liquid pipeline systems, as was reported by Afanasyev et al. [45]. The authors revealed that the variables affecting the distribution of SCC could be attributed to the low resistivity (about $100 \mathrm{ohm} . \mathrm{cm}$ ) of the soil brine, prolonged exposure time (up to 20 years of operation in real conditions), location, pipeline inclination (degree), elevation profile, large diameter, long pipeline network (pipeline sections: around length of $25 \mathrm{~km}$ ), large diameter of the pipeline, random operating pressure, and temperature. As a result, significant degraded coating could be achieved where growth in depth and opening width (wide variation of lengths and widths), and possible anomalies-defects-indications (defect population grown for 20 years) must be taken into consideration. It can lead to induced crack or fracture propagation in E-SCC. Crack length-to-width ratio and width-to-depth ratio may be studied using a cyclic test simulating a constant load similar to the operational load. In addition, they concluded that the proposed methodology can be applied when actual samples are correlated with the inline inspection technology (ILI) measurements to combat the negative effects supporting the ILI data analysis and avoid hard choices (including excavations) during the validation of prioritization in the integrity assessment [46]. It is overly important to mention that external loads (natural or applied loads including gravity and weight) presence could also affect the coated pipeline from extended sections. For that reason, damaged coating and SCC occurrence may be achieved in large diameter steel pipelines.

\subsection{When SCC Occur}

Figure 1 shows the main factors required for guideline E-SCC and I-SCC to be presented in a metallic material.

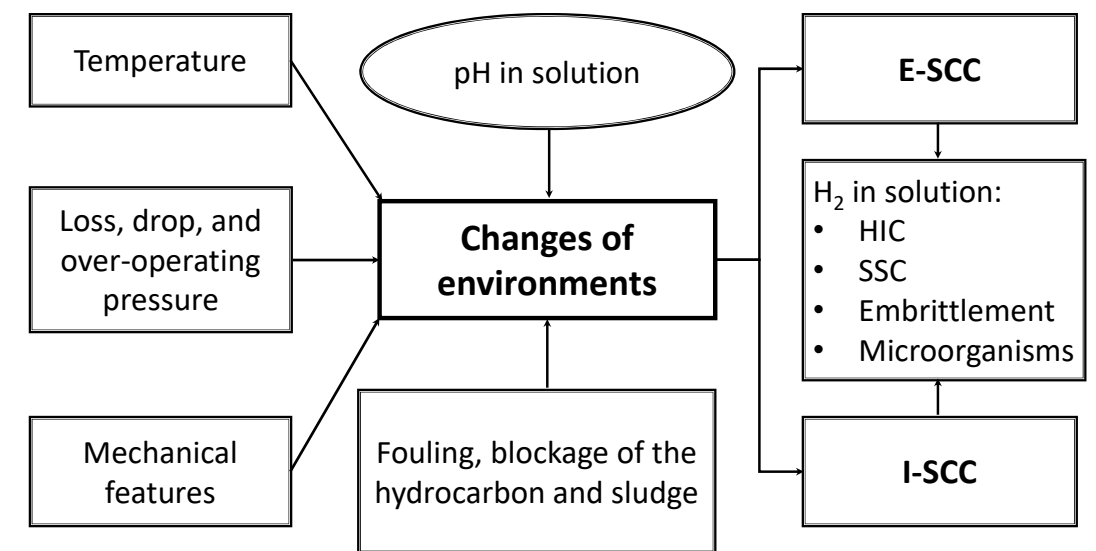

Figure 1. Main factors required to develop stress corrosion cracking (SCC).

The presence of the SCC is not always visible (visual inspection in field experiences), but this defect is dangerous, especially when it is found like colonies of cracks, which coalesce as the time evolves to cause ruptures. It is a phenomenon that can happen unexpectedly and quickly after a satisfactory period of service, leading to a catastrophic failure in pipelines. The main variables that have an effect on the SCC from OD and inside diameter (ID) are:

OD

- Water;

- Environment;

- $\mathrm{pH}$ in soil;

- Electrolytes in soil; 
- Steel grade;

- Chemical composition;

- Microstructure;

- Hardness;

- Toughness;

- Elasticity;

- Elongation;

- Fatigue;

- Type of welding;

- Cathodic protection;

- Type of coating;

- Microorganisms.

ID

- Water;

- Electrolytes in water (oilfield produced water);

- $\mathrm{pH}$ in solution;

- Hydrocarbon transported;

- Chemical treatment application;

- Pressure;

- Temperature;

- Flowing media;

- Microorganisms;

- Internal coating.

\subsection{Origins of Stresses}

Cheng [1] reported that the interaction between metallurgy, aggressive environment, and the applied or residual stress on operating pipelines coexist. The residual stress refers to a natural stress state, which is held in a metal in the absence of external load, gravity, thermal gradient, among other source of stresses [47]. Applied stress come from pressure-microstructure manufacturing. It could occur from plastic deformation (rolling, extruding, bending, and forming), elastic deflection, manufacturing process (welding, machining, and electrodeposition), heat or thermochemical treatment (quenching and ion plating) [48-51].

\subsubsection{Microstructure}

Data acquired from the interaction-reaction effects depend on the specific environment promoting the cracks or fractures occurrences. In the case of metallurgy this is related to susceptible sites such as microstructural features (chemistry, alloying elements, texture, grain size, shape distribution, secondary phases, random, special grain boundaries, and intergranular degradation) becoming anodic affecting the susceptibility to SCC at certain type of cracks and fractures [1,2,52]. In some cases, the SCC problem appears to be a poor manufacturing process for carbon steel pipelines. This problem could be increased when incorrect finished surface may occur, where the expected susceptibility to corrosion, SCC occurrence, and failure frequency are a complicated process. However, microstructural features are strongly affected from the corrosiveness of the environment. Thus, active electrochemical reactions are expected on cracks-fractures/test solution interfaces where the values for mechanical features for steels go up increases by using a standard tensile test $[8,44,53]$. The interactions between the physicochemical, mechanical, and electrochemical factors depend on many variables, such as changes of the corrosive media and residual or applied stresses resulting in several forms of corrosion and 
microstructural damage (microstructural degradation) [34,35]. SCC may be included in the HIC, hydrogen embrittlement, and SSC that comes from the testing of steels in hydrogen sources from the over-voltage during the cathodic protection, representative soil solutions, carbonates, bicarbonates, acidic soils, acidic atmospheric compounds, organic acids, external bacteria induced corrosion, among other data $[1-3,34,35]$.

\subsubsection{Testing}

The mechanical testing may be addressed by four stages to study the crack growth rate in SCC mechanisms using slow strain rate tests (SSRT) or constant load (CL) such as (a) initiation conditions develop (nucleation), (b) cracks initiate with slow growth, (c) growth by continuous initiation, extension, and coalescence, and (d) large cracks coalescence with propagation and failure [1,54].

\subsection{Techniques Used for Assessing SCC}

Perhaps the three techniques most used to assess SCC are (1) slow strain rate tests (SSRT) using constant extension rate machine, (2) constant load tests (CLT) using proofs rings and (3) small punch tests (SPT) using miniaturized specimens. Sometimes these techniques are combined with electrochemical measurements in order to monitoring the SCC process.

The SSRT is a mechanical technique for studying cracking environments of buried pipelines. It is widely applied for E-SCC and I-SCC evaluations of carbon steels pipelines. The SSRT technique involves the slow straining of a specimen of the steel of interest in a solution in which will be in service. This technique provides useful information on SCC susceptibility of the actual pipeline steels exposed to external and internal solutions, in addition to a relatively short experimental time to evaluate SCC susceptibility of metal materials [55-58]. There are several mobile constant extension rate machines used in the SSRT to determine SCC susceptibility of metals exposed to corrosive environments $[59,60]$.

In addition, various types of proof rings are used to evaluate SCC a constant load (@)2017 CORTEST and all work represented. All rights reserved). These tests are performed generally at higher stress than yielding strength. The samples are exposed to a corrosive environment for 30 days and the criterion applied is pass/no pass; if material did not failed pass and not pass if material failed. These tests are carried out according to ANSI/NACE TM0177 [61]. Some limitations of proof rings are that is a static test, evaluate the elastic zone, material could not fail, relaxation could occur over the time, the SCC process is not monitored, the test is performed at only determined stress, long time of tests, among others.

To evaluate some mechanical properties of metal materials there is a small punch test (SPT) $[62,63]$. It consists of evaluating susceptibility to SCC using a small punch and acoustic emission (AE). Typically, $10.0 \times 10.0 \times 0.5 \mathrm{~mm}$ specimens are tested at various deformation rates; the amplitude of the AE signal is captured and the equivalent of fracture deformation and susceptibility to SCC of high-strength steels is taken. Because of the small size of the specimens that the punch test uses, it is an appropriate experiment for mechanically characterizing small areas, which it would not be possible to analyze with the other two types of tests. The SPT assay is currently being used to determine the mechanical properties related to axial and biaxial state of tension in the small punch test, ductile-brittle transition temperature, the fracture and creep behavior, as well as a study related to the SCC susceptibility of metals to environmentally assisted cracking (EAC) [53].

\section{SCC Assessment Using SSRT}

SCC susceptibility is commonly tested according to NACE TM0198 and ASTM G129 [44,53]. The deterioration by SCC is fundamentally evaluated by differences in the behavior of the mechanical properties of the specimen in tests conducted in a particular environment (soils or solutions from external and internal environments, respectively) from that obtained from evaluations obtained in air, including equations and criteria used in the assessment $[44,64,65]$. The tendencies (ratios) of metals to ductility parameters such as plastic strain-to-failure ratio $=$ (plastic strain-to-failure in the 
test environment/plastic strain-to-failure in air) $\times 100$ must be addressed [44]. Thus, ratios of plastic strain-to-failure about 0.8-1.0 means low susceptibility to EAC, whereas low values (i.e., <0.5) show high susceptibility. To increase the SCC resistance, values of plastic strain-to-failure ratios near 1.0 is recommended. Spectroscopic and mechanical evaluations of the specimen are recommended to establish whether or not SCC must be achieved from a plastic strain-to-failure ratios lower than 0.8 . Thus, crack properties must be tested on the longitudinal section of the gage.

In order to achieve a homogenization related to testing techniques in industrial and academic fields, a status of standardization was reported by Kane and Wilhelm since 1993 [66]. Recently, the techniques widely used for assessing the SCC susceptibility of carbon steels are the SSRT and the constant load testing (CL) $[44,53,67]$. In the first, a constant extension rate tests (CERT) in an Inter-Corr machine type M-CERT with a specific load capacity $(44 \mathrm{kN})$, total extension of $50 \mathrm{~mm}$, and a strain rate of $1 \times 10^{-6} \mathrm{~s}^{-1}$ for carbon steels was used and a SCC analysis may be carried up to 3 days of exposure time [44,53]. Typically, cylindrical or rectangular SSRT tensile specimens may be machined for assessing SCC phenomenon depending on the tension test machine and experimental conditions. The specific measures of the SSRT test specimen (size, shape, and type), experimental procedure, and corrosive media detail are given in NACE Standard MR0103, NACE Standard TM0169, NACE Standard TM0177, ASTM G129, and NACE Standard TM0198 [61-69]. In the second, bent beam, C-ring, U-bend, specimens for weldments, precracked wedge open loading type, precracked, cantilever beam, and Bent-Beam are some recommended specimens for assessing SCC of carbon steels [61,70-73]. In this way, a constant load (tensile stresses) is applied on specimens exposed to solution promoting cracking for an evaluation of long duration (up to one month).

Other SCC testing detail is given in NACE Standard TM0284 [74]. New materials (including polymer compounds or composite coatings), good test duplication including the reference (inert environment such as air), allows SCC susceptibility of materials to be analyzed at relatively short test-time, uses terms familiar to engineers or researchers, enables corrosion testing of weldments specimens to be analyzed, and failure analysis by cracking in operating pipelines ruptures must be determined. They can be tested in the absence (reference) and in the presence of corrosive solution. In addition, combining electrochemical techniques can be applied to the assessment of simultaneous corrosion process and tension tests [8]. However, it is extremely important to isolate the electric contact of the specimen from all tension test machine structures. This enables different cracks, brittle zones, fractures, and deformed grain zones to be studied by electrochemical and spectroscopic methods, which are more reliable in comparison with those in CL. In addition, some cautions and limitations are: (1) anomalous behavior of the SCC test is related to inadequate control or measurement of strain rate or potential, (2) not correlation by combining electrochemical (impedance or polarization curves) and SCC methods is given for interpretation data from operating pipelines (field scenarios and dig data in buried pipeline such as longitudinal stress, circumferential stress, axial crack, transverse crack, circumferential crack, oblique, and not oblique-circumferential neither oblique or circumferential stacking of axial cracks), (3) usually applicable to high strength materials, (4) may oversimplify initiation stage of cracking as well as specimens could be large and expensive to machine compared with some smooth specimens $[1,75]$.

In addition, Afanasyev et al. [45] proposed a cyclic test simulating a real load from a field scenario to determine the variables affecting the cracks and fractures (in the absence of corrosive environment) concerning the wide variation of lengths and widths [73]. In this test, the methodology consists of cyclic tests of several damaged samples from real field conditions were four-point loading conditions is applied [73]. The applied load (cyclic pressure change or cyclic test modes) can be simulated from the whole range of pressure fluctuations from the upper and lower half-periods over a representative period of a specific operating pipeline. 


\subsection{Complementary Test Methods for Assessing SCC}

Some experimental tests related to SCC and electrochemical responses have been reported [68,76-80]. Most notably, standard recommended practices for complementary external SCC studies may be ASTM G57 and ASTM G187 for the soil resistivity determination by using a soil resistivity meter; moisture content using a gravimetric method which is recommended by ASTM D4959, and ASTM G4643 using direct heating or microwave oven heating, $\mathrm{pH}$ value using a potentiometer and the ASTM G51, redox potential analysis using a potentiometer and ASTM G200, texture characteristics, oxygen concentration, metal and anions content using the inductively coupled plasma (ICP) and ion chromatography, cathodic disbonding evaluations recommended by ASTM G8, ASTM G 42, ASTM G80 or ASTM G95, as well as the NACE Standard TM0497 related to criteria for cathodic protection on buried pipelines, ASTM G62 for holiday observation in coatings, NACE Standard TM0106 for studies of microbiologically influenced corrosion, and ANSI/NACE Standard RP0502 for pipeline external direct assessment [81-95]. In addition, the electrochemical data acquired from the cyclic tests proposed by Afanasyev et al. [45] were studied using fractography analysis from cross section samples. Based on the spectroscopic analysis this is a technique used to obtain elemental composition of corrosion products (oxides) from maps of elements distribution in a SCC [45]. The standards recommended practices for complementary evaluation of I-SCC are: NACE Standard SP0206 for direct assessment of internal corrosion in pipelines transporting dry natural gas, and NACE Standard SP110 for direct assessment for pipelines in wet natural gas $[96,97]$. Additional standard recommended tests for internal studies include: texture characteristics, oxygen concentration, metal and anions content using the inductively coupled plasma (ICP) and ion chromatography, redox potential analysis using a potentiometer and ASTM Standard G200, ASTM Standard D4294 for petroleum and petroleum products containing sulfur compounds, ASTM D287 or ASTM D1298 for American Petroleum Institute (API) gravity test in hydrocarbons to know its viscosity grade, ASTM D664 for acid number of hydrocarbons, oil viscosity, oil density, ASTM D5002 for density, relative density, and API gravity of crude oils, water (water cut) and sediments by centrifuge method, $\mathrm{pH}$ of water, water in crude oil by distillation, metals, chlorides, sulfates, conductivity and resistivity in water, iron in water, bacteria, biocides, among others $[86,87,98-116]$.

\subsection{How to Prevent SCC and Factors that Affect Its Evolution}

Pipeline companies, industrial groups, and researchers have observed ways to prevent, detect or remove SCC before they grow to the point where pipeline failure can occur. Perhaps, the pioneer and most advanced country in these studies is Canada thorough the National Energy Board, followed by USA [54]. This has resulted in the publication by the Canadian Energy Pipeline Association of a set of practical recommendations and more recently of a comprehensive review of SCC that has been carried out by Michael Baker and associates on behalf of the U. S. Office Pipeline Safety [117]. The results of research, techniques used, and experience gained have resulted in a continuous increase in useful information. This will continue to happen this way as long as there is additional research in this area. All these points together have improved the understanding of SCC and have helped to formulate procedures for the study of SCC mechanism. In order to reduce the risks due to SCC, you should do:

- A suitable selection of the pipeline steel;

- Stress control (residual, operation, external loads);

- Remove critical species from the environments $\left(\mathrm{H}_{2} \mathrm{~S}, \mathrm{CO}_{2}, \mathrm{Cl}^{-}\right.$, among others);

- Suitable cathodic protection ranges (avoid over cathodic protection);

- Select the appropriated coating.

Figure 2 describes the main factors that must be considered to prevent that internal and external SCC develop in a pipeline. The parameters that must be considered to prevent SCC development in pipelines according to factors mentioned above are describe in the following section. 


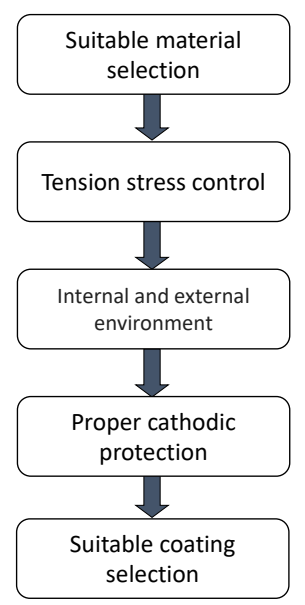

Figure 2. Factors that must be considered to prevent SCC development in pipelines.

\subsubsection{Suitable Material Selection}

The material selection is one of the main factors that must be considered to prevent SCC development in pipelines, and these factors must be taken into account:

- Use materials with low SCC susceptibility;

- Good quality (low inclusions, porosity, among others);

- Proper toughness steels;

- Suitable microstructure to avoid SCC.

Taking into account the last studies considering the SCC susceptibility of the material, we have the following remarks:

- The greater the API steel grade, the higher strength but greater the susceptibility to SCC;

- All low carbon steels have certain degree of SCC susceptibility;

- The greater the hardness of steel, the greater the susceptibility to SCC;

- Higher quality steels have lower susceptibility to SCC;

- Steels with microstructure of bainite and acicular ferrite have a lower susceptibility to SCC.

\subsubsection{Tension Stress Control}

The tension stress in pipelines must be controlled and reduced in order to avoid development and growth of cracks in materials susceptible to SCC. The parameters that could be considered are:

- Proper heat treatment to reduce residual stresses;

- Cold expansion to reduce residual stresses;

- Pressure fluctuation control;

- Reduce operating pressure.

\subsubsection{External and Internal Environment}

The internal and external parameters related to the environment must be considered in order to reduce the possibilities of nucleation and growth of cracks in materials susceptible to SCC.

The next are some of the parameters that must be addressed:

- Remove corrosive species in the fluid transported like $\mathrm{Cl}^{-}, \mathrm{H}_{2} \mathrm{~S}, \mathrm{CO}_{2}$, Sulfates.

- Remove standing water in pipelines;

- Soils with high content of carbonates $\left(\mathrm{CO}_{3}{ }^{2-}\right)$ are prone to develop SCC;

- Use inhibitors sometimes helps to avoid corrosion and SCC;

- Proper coatings in corrosive soils. 


\subsubsection{Proper Cathodic Protection}

The proper levels of cathodic protection are important to avoid dissociation of water that generates monoatomic hydrogen that ingresses in the material producing embrittlement. The parameters that must be considered are:

- Suitable cathodic protection;

- Avoid over cathodic protection;

- Resistant coating for over cathodic protection;

- Interferences of direct current.

\subsubsection{Suitable Coating Selection}

The suitable selection of coating is one of the most important parameters that must be taken into account to prevent SCC development in pipelines, because the coating is the physical barrier that must be avoid the contact between the electrolyte and metal materials, and these factors must be taken into account:

- Use high performance coatings;

- Good surface preparation;

- Coating with good adhesion;

- Use of compatible coatings.

\subsection{How SCC May Be Controlled in Carbon Steel Pipelines?}

In field practices, the external corrosion for buried, submarine, and atmospheric pipelines may be controlled using anticorrosive and improved coating (enhancement polymer or epoxy materials) as a physical barrier, cathodic protection systems, materials, and environment.

\subsubsection{Coatings}

To protect the external damage of carbon steels, organic coatings continue to be a topic of great research interest. Organic and epoxy resin coatings have low shrinkage and deterioration, and high chemical and mechanical characteristics. They can be applied on ships, oil tanks, seabed and buried pipelines [118,119]. The purpose of the coating is to prevent the corrosion and avoid the direct contact between the carbon steel surface and the external variables containing hydrogen to promoting SCC $[1,4,5,17,24]$. The type of coating that is applied commonly on external surfaces of the operating pipelines are epoxy, wax, polyolefin resin coating, coal, cement, composites, or alkyd, such as fusion bonded epoxy (FBE), liquid epoxy, urethane, asphalt, coal tar, multilayer or composite coating, poly(methyl methacrylate) PMMA, asphaltic compounds, polyethylene (PE), viscoelastic (plasticity of coating used) polymer, among other $[1,3,5,7,9,10,120-124]$. They are applied to protect the external pipeline with good mechanical properties, poor permeability to water, effective electrical insulation, good adhesion, adequate thickness, and high resistance to degradation with time [1]. Based on FBE this is an epoxy coating used to resist the mechanical damage during the handling, storage, construction, and installation in new large diameter pipelines. It is applied to maintain high resistance to hydrocarbons, acids, and alkalis [3]. However, FBE is susceptible to cathodic protection, producing blistering or shielding effects [1]. Deteriorated or aged coating could occur when external SCC is an influence, because the performance of the coating may be affected by the residual or applied stress of the operating pipelines, and this depends on the exposed soil or atmospheric environment type, including the environmental changes, protection systems, possible incorrect mixing ratio of the coating, and incorrect surface degreasing and preparation. 


\subsubsection{Cathodic Protection}

One way of reinforcing and supporting the external coatings against the external damage is the application of an impressed current or sacrificial anodes (cathodic protection systems). In this way, the external corrosion for coated and buried pipelines is controlled by the type of the coating, soil, seabed, and its physicochemical modification due to change of season, which in turn localizes the damage condition of the coating as well as the cathodic protection, that could be displaced toward negative behavior. The negative behavior is related to the presence of carbonates, disbonded coating, hydrogen production, external SCC, blistering and shielding effects on the high performance coating (Cheng, 2013; Beavers and Thompson, 2006). The standard used to achieve the external corrosion control on buried pipelines is NACE SP0169 [125]. Some Standard methods for disbonded coating studies are ASTM G8, ASTM G42, ASTM G 80, and ASTM G95 [88-91].

\subsubsection{Materials and Microstructure}

Single-phase microstructures (excluding precipitates) generally provide a higher resistance to SSC than a multiphasic structure. Most of the fractures produced by the SSC often begin in internal locations of the material, in places of high concentration of internal stresses, while the SCC frequently starts on the surface of the metal from cracks or pitting. In the aspect of hydrogen embrittlement, the effect of damage occurs in two places, at the tip of the crack directly generating the material's cohesion, or internally between the sites of hydrogen run-off given mainly at the grain edges and defected crystalline. The exact composition of the alloy and its microstructure, as well as the heat treatment applied, have a marked effect on the development of the SCC. The process of embrittlement by hydrogen on steels is somewhat significant to the strength of the metal, additionally, these materials have a lower critical stress intensity factor, with the fracture occurring more quickly being associated with a smaller crack size. The type of alloy elements in carbon steel pipelines is especially important to the SCC mechanism, as over time these changes can occur due to the natural aging of the materials. An effect such as the formation of segregated phases on the grain edges of the elements of alloy can be distinguished more clearly in the span of about 20 years of the pipelines in service. An example of this is greater occurrence of fractures and leaks associated with the SCC that have occurred in the United States of America and Canada [126]. The microstructure of the carbon steel pipelines contain a ferrite-pearlite phase. Homogeneous microstructures may be less susceptible to SCC [127-132]. However, these steels have traces of sulfur forming manganese sulfide inclusions (MnS). Other inclusions are aluminum oxides, calcium oxides, and calcium sulfide. According to Liu et al. [133] the origins of the crack initiation sites must be due to the inclusions. The authors said that inclusions enriched in $\mathrm{Al}_{2} \mathrm{O}_{3}$ and $\mathrm{SiO}_{2}$ can form a hard, brittle, and incoherent character on metal matrix. Micro cracks and interstices are fundamentally formed in the grain boundary, and around of the inclusions. Asahi et al. [128] measured the threshold stress of X52, X65, X80 steels by different thermal treatment. The authors concluded that the thermomechanically controlled processed (TMCP), and quenched-tempered (QT) on these steels, achieved more uniform microstructures, were less susceptible to SCC. Thus, the microstructure of carbon steel pipelines has been considered one important factor affecting SCC initiation and propagation [64,65,127-132]. Therefore, the SCC resistance of carbon steel pipelines can be increased by eliminating the inclusions or precipitates content to avoid the nucleation sites for corrosion pits on carbon steels [64,65,132-134].

\subsubsection{Environment}

SCC is attributed to the soil and the fluid transported - the external environment and internal environments-which concern different external and internal corrosion mechanisms. SCC is highly relevant to economics, environmental damages, pollution and safety needs, which are all expected to be monitored globally $[54,65,126,135-160]$. Thus, the principal problem induced by ions-mainly, naphthenic acid content, partial pressure, temperature, $\mathrm{CO}_{2}$ and $\mathrm{H}_{2} \mathrm{~S}$-is the E-SCC and I-SCC. 
Concerning the environments relating to physicochemical properties, nearly neutral $\mathrm{pH}$ and high $\mathrm{pH}$ in soils and representative soil solutions containing carbonates are some conditions where SCC occurrence were highlighted [159]. SCC increases with the high cathodic polarization simulating an overprotection on carbon steel [14,161-163]. In this case, a good coating should be applied. The nearly neutral pH SCC of carbon steel pipelines is related to tape disbonds in coatings, which are able to produce carbonates from $\mathrm{CO}_{2}[4,6,7,17,19,124,161,163,164]$. High $\mathrm{pH}$ values are related to SCC failures where $\mathrm{CO}_{3}{ }^{-2}, \mathrm{HCO}_{3}{ }^{-}$, and alkaline SCC damage is conferred $[21,27,165]$. In addition, Yin et al. [166] mentioned that $\mathrm{CO}_{2}$ gas can dissolve in the presence of water producing carbonic acid, which is an aggressive solution to carbon steel. Hydrogen production on carbon steels from sulphate-reducing bacteria or acidic soil solution sources may occur $[15,18,24,133]$. Thus, possible SCC occurrence under the defected coating from pipelines could be achieved promoting an extreme condition [167]. This is because damaged coating is a local defect where the cathodic protection level (low or high) is strongly influenced. This negative manifestation is increased when the external applied coating on pipelines is corrugated in specific places during the construction and installation of the pipelines in the form of mechanical damage as was reported by Afanasyev et al. [45]. When the physicochemical properties of the soils (including air, oxygen, water, and solid particles), and their possible mechanical effects become random and prolonged, the corrugated coating are subject to an abrupt dried or saturated conditions (depending on the seasonal fluctuations in a specific location) resulting in more corrosive environment as extreme situations $[9,11]$. Carbon steel corroded surfaces can be attributed to the suddenly changes of the environment such as seasonal period, which in turns modifies the levels of the cathodic protection systems and the physicochemical properties of the soils [9]. The above means that buried pipelines can be affected by extreme stages during the change of season. Soils containing variable moisture (low and high weight percent of water) can modify their physicochemical properties for each season of the year and they could provoke a random climate for buried pipeline steel. For that reason, random modifications of the mechanical properties, ion concentrations of the soil, and electrochemical responses on pipeline steel-soil interface are expected. For geological purposes and scientific studies, it is important to mention that natural soils should be collected at the bottom of a buried pipeline (around $1.2 \mathrm{~m}$ in depth) from a right of way (ROW) where severe external corrosion damage could be identified [10]. Romanoff [168] has mentioned that the external corrosion for metallic structures is affected by metal types in the absence and in the presence of coating immersed in different soils located through the United States. In addition, Cole and Marney [25] reported that the corrosion process for metallic materials exposed to soils can be attributed to electrochemical reactions, oxide effects, the impact of the physicochemical properties such as temperature, moisture content, salinity, $\mathrm{pH}$ value, and void fraction, mainly. The authors concluded that among all parameters, different codes, models and methodologies occupies important tools to predict and prevent the external corrosion for buried pipelines transporting water, sewerage and oil and gas systems.

In field scenarios, the internal SCC of carbon steel pipelines could be arrested or minimized using a field separator device to remove the corrosive gas, hydrocarbon, water cut (oilfield produced water containing high salt contents), and possible sludge containing solids, metals, and sediments, which include a desalting and dehydration processes. Internal SCC occurrences could be activated by the nature of the fluid (fluid composition) containing $\mathrm{CO}_{2}, \mathrm{H}_{2} \mathrm{~S}$, organic acids, water content, density (gas and liquid), viscosity, dissolved oxygen, microorganism, suspended solids, and field sludge [169]. Moreover, the stronger interaction with the pipeline operating condition including the temperature (inner wall, fluid, gas, and liquid), the rate (gas, liquid, deposition, erosion velocity), heat transfer, surface shear stress, flow pattern (turbulence intensity), and pressure is highlighted. In the last variable, fouling propensity influence is attributed to the suspended solids, and field sludge resulting in an over-operating pressure during the production, gathering, storage and transportation of hydrocarbons through pipelines. As a result, an increase in operational cost and product yield reduction is conferred. Thus, anticorrosion measures using chemical treatments (corrosion inhibitor programs) 
and direct (corrosion coupons, failure frequency, inline inspection using smart pigs, radiographic testing, ultrasonic testing, among other methods) or indirect (water cut, liquid analysis, microbiological components, inhibitor traces, gas analysis, solids analysis, hydrogen flux, temperature, pressure, among other data) corrosion monitoring for internal pipelines is required [94,116,170-172]. It is well known that an activity/operation related to fouling tendency in oil pipelines is the in-line cleaning systems using a pig tool (pigging for cleaning the pipeline), same with gas pipelines but uses a sphere not a pig [46].

\subsection{SCC Originates from Pits}

SCC testing is related to pit-crack transition processes including microvoids and other types of discontinuities, as is shown in Figure 3 [59]. Thus, unpredictable pits-cracks initiation and propagation including the plastic deformation, tensile residual stresses (stress intensity parameter), and corrosion fatigue and the stage of SCC models are taken into consideration [59,173-182].


Figure 3. Schematic representation of the pit to crack transition [59]. (a) pit initiation, (b) pit growth, (c) crack start, and (d) final crack.

\section{Parameters Reported in the Literature Regarding the External SCC}

In empirical and theoretical practices, corrosion damage modeling and the effect of several field scenarios are related to SCC analysis, where the operating pipelines exposed to different external variables (types of electrolytes, temperature, $\mathrm{pH}$, among other data) have been studied and reported in the literature [20,168,183-188]. Nowadays, SCC of carbon steel pipelines is increasing in popularity, and the original mechanical properties of the steels and their initial electrochemical interactions with natural soils, representative soil solutions, or any solution promoting cracking have been described including SCC, intergranular-SCC (IG-SCC), transgranular-SCC (TG-SCC), SSC, $\mathrm{HIC}$, hydrogen embrittlement from testing and characterization of carbon steels in hydrogen or sour testing [8-11,189]. In this way, metallurgy, physicochemical properties, codes, mathematical models, and electrochemical responses to predict external corrosion in terms of $\mathrm{pH}$ value, redox potential, resistivity, and pipe-soil potential can be considered [184-186,190]. Some empirical (generic) crack assessment models regarding SCC are API 579 and BS 7910 [191,192]. However, SCC occurrence is still not well understood (including the generic SCC models) and requires more experimental research. Carbon steel pipelines exposed to aggressive and external variables are the main causes of unpredictable cracking and fracture initiation mechanisms. Additional information on physicochemical, electrical, and mechanical testing and evaluations for external environments of operating pipelines may be found in Section 2.3. Table 1 shows some external parameters and environment to promoting the external cracking [43,193-197]. 
Table 1. Main external environments affecting operating pipelines to develop SCC.

\begin{tabular}{ccccccc}
\hline Factors & \multicolumn{5}{c}{ Parameters } & Ref. \\
\hline Chemical & $\mathrm{pH}$ & Carbonates & Organic acids & Ions & Mass loss & {$[43]$} \\
Electrical & Soil resistance & Potential & Current & Redox potential & Resistivity & {$[43]$} \\
Physical & Soil, seawater, & Moisture & Temperature & Coating & Exposure time & {$[9,10,195]$} \\
Biological & $\begin{array}{c}\text { Seabed, atmospheric } \\
\text { Organic mater }\end{array}$ & Nutrients & Biofilm formation & Bacteria & Fungi & {$[197]$} \\
\hline
\end{tabular}

According to this Table 1, the external corrosion for buried pipelines is attributed to different types of physical, chemical, mechanical, electrical and biological environments. As a result, the possible reduction of the original mechanical features for pipeline steels could occur [8]. After a brief review, the experimental data based on the range of variables studied and reported in the literature regarding the external SCC of carbon steel pipelines were selected. Data acquired from the reviewed experimental part are documented in Tables 2-6. Tables 2 and 3 are related to reviewed physicochemical properties [4-7,9,11,14-19,59,124-203]. Variables listed in Table 4 are related to reviewed mechanical properties, while Tables 5 and 6 are associated to reviewed electrochemical properties $[4,9,11,15-19,23,24,36,124,133,159,163-165,198-203]$.

Table 2. Reviewed physicochemical properties for external corrosion studies.

\begin{tabular}{|c|c|c|c|c|c|c|c|c|}
\hline Steel & Coating & Electrolyte & $\mathrm{pH}$ & $\begin{array}{l}\text { Moisture } \\
\text { (wt \%) }\end{array}$ & $\begin{array}{l}\text { Redox Potential } \\
\text { (mV vs. Ag/AgCl) }\end{array}$ & $\mathrm{T}\left({ }^{\circ} \mathrm{C}\right)$ & $\begin{array}{l}\text { Conductivity } \\
(\mathrm{mS} / \mathrm{cm})\end{array}$ & Ref. \\
\hline X70 & FBE & $\mathrm{Na}_{2} \mathrm{CO}_{3}+\mathrm{NaHCO}_{3}+\mathrm{NaCl}$ & 9.4 & - & - & 21 & 61.5 & [4] \\
\hline X65 & FBE & $\mathrm{Na}_{2} \mathrm{CO}_{3}+\mathrm{NaHCO}_{3}+\mathrm{NaCl}$ & 9.6 & - & - & 22 & 21.8 & [6] \\
\hline X70 & Polyethylene & NS4 & 6.8 & - & - & 22 & - & [7] \\
\hline X52 & - & Sand soil & - & $1.5 / 25$ & - & 20 & - & [9] \\
\hline X52 & - & Clay soil & - & $25 / 39$ & - & 20 & - & [9] \\
\hline X52 & - & Marshy soil & - & $25 / 53$ & - & 20 & - & [9] \\
\hline X60 & $\begin{array}{l}\text { Damaged } \\
\text { viscoelastic } \\
\text { polymer }\end{array}$ & Sand soil & 6.53 & 25.1 & 305 & 20 & - & [9] \\
\hline X60 & & Clay soil & 7.47 & 33.4 & 280 & 20 & - & [9] \\
\hline X60 & & Clay-Silt soil & 7.21 & 52.3 & 285 & 20 & - & [9] \\
\hline X52/X80 & - & Clay soil & 7.3 & $5.1 / 39.7$ & $50 / 373$ & 20 & - & [11] \\
\hline X70 & - & NS4 & $6.3 / 6.5$ & - & - & 22 & - & [14] \\
\hline X80 & - & Soil solution & 4.0 & - & - & 20 & - & [15] \\
\hline X80 & - & Red soil & 4.9 & - & - & 20 & 0.018 & [17] \\
\hline X70 & - & Red soil & 4.41 & - & - & 22 & 0.018 & [18] \\
\hline X52 & - & $\mathrm{Na}_{2} \mathrm{SO}_{4}$ & $6.2 / 8.0$ & - & - & $25 / 80$ & - & [19] \\
\hline$X 52$ & - & Calcareous soil & 8.1 & 22.5 & 335 & 20 & & [59] \\
\hline X70 & PMMA & Sand & 9.6 & - & - & 20 & - & {$[5,124]$} \\
\hline
\end{tabular}

Table 3. Continued reviewed physicochemical properties for external corrosion studies.

\begin{tabular}{|c|c|c|c|c|c|c|}
\hline Steel & Coating & Electrolyte & $\mathrm{pH}$ & $\mathrm{T}\left({ }^{\circ} \mathrm{C}\right)$ & $\begin{array}{c}\text { Conductivity } \\
(\mu \mathrm{S} / \mathrm{cm})\end{array}$ & Ref. \\
\hline X70 & - & $\mathrm{Na}_{2} \mathrm{CO}_{3}+\mathrm{NaHCO}_{3}+\mathrm{NaCl}$ & 9.6 & - & - & [16] \\
\hline X80 & - & Meadow soil + SRB & 7.75 & - & - & [23] \\
\hline X70 & - & $\mathrm{NaCl}+\mathrm{Na}_{2} \mathrm{SO}_{4}+\mathrm{NaHCO}_{3}+\mathrm{SRB}$ & 8.8 & $4 / 121$ & - & [24] \\
\hline X80 & - & Acidic soil solution & 4.6 & - & 212 & [36] \\
\hline X80 & PMMA & NS4 & - & - & 950 & [124] \\
\hline X70 & - & Soil-extracted & 4.0 & - & - & [133] \\
\hline X52 & - & NS4 & 6.8 & 27 & - & [159] \\
\hline X65 & - & NOTW & 7.1 & - & - & [160] \\
\hline X70 & - & $\mathrm{Na}_{2} \mathrm{CO}_{3}+\mathrm{NaHCO}_{3}+\mathrm{NaCl}$ & 9.6 & 22 & - & [162] \\
\hline X70 & - & NS4 & 6.3 & 22 & - & [163] \\
\hline X70 & - & NS4 & 6.5 & 22 & - & [164] \\
\hline X70 & - & $\mathrm{Na}_{2} \mathrm{CO}_{3}+\mathrm{NaHCO}_{3}$ & 9.3 & 50 & - & [165] \\
\hline $\mathrm{X} 100$ & - & NS4 & 6.8 & 22 & - & [198] \\
\hline X80 & - & Meadow soil/SRB & 7.75 & 22 & - & {$[199,200]$} \\
\hline X70 & - & NS4 & 7.0 & 22 & - & [201] \\
\hline X80 & - & $\mathrm{Na}_{2} \mathrm{CO}_{3}+\mathrm{NaHCO}_{3}$ & 9.32 & - & - & [202] \\
\hline S235JR & - & VMNI, wolfe's, vitamin; G. Sulfurreducens & - & 25 & - & [203] \\
\hline
\end{tabular}


Table 4. Reviewed mechanical properties for external corrosion studies.

\begin{tabular}{cccccc}
\hline Steel & YS (MPa) & UTS (MPa) & E (GPa) & EL (\%) & Ref. \\
\hline X70 & 650 & - & - & - & {$[4]$} \\
X60 & 467 & 567 & 201 & 40 & {$[9]$} \\
X52 & 396 & 498 & 258 & 40 & {$[11]$} \\
X60 & 513 & 567 & 292 & 39 & {$[11]$} \\
X65 & 559 & 602 & 298 & 37 & {$[11]$} \\
X70 & 577 & 660 & 295 & 32 & {$[11]$} \\
X80 & 575 & 738 & 302 & 23 & {$[11]$} \\
X80 & 516 & 625 & - & - & {$[15]$} \\
X80 & 581 & 655 & - & - & {$[17]$} \\
X70 & - & 650 & - & - & {$[18]$} \\
X52 & 358 & 455 & - & - & {$[19]$} \\
X80 & 650.7 & 694.3 & - & - & {$[23]$} \\
X80 & 581 & 655 & - & - & {$[124]$} \\
X70 & 600 & - & - & - & {$[163]$} \\
X100 & 800 & 870 & - & - & {$[198]$} \\
X80 & 580.2 & 665.2 & - & 70 & {$[200]$} \\
X80 & 560 & 635 & - & - & {$[201]$} \\
S235JR & 406 & 510 & - & - & {$[203]$} \\
\hline
\end{tabular}

Table 5. Reviewed electrochemical properties for external corrosion studies.

\begin{tabular}{|c|c|c|c|c|}
\hline Steel & $\begin{array}{l}\text { Corrosion Rate, } \\
\text { CR (mm/Year) }\end{array}$ & $\begin{array}{l}\text { Corrosion Potential, } \mathrm{E}_{\text {corr }} \\
\left(\mathrm{mV} \text { vs. } \mathrm{Cu} / \mathrm{CuSO}_{4}\right)\end{array}$ & $\begin{array}{c}\text { Charge Transfer } \\
\text { Resistance, } R_{\mathrm{ct}}\left(\Omega \cdot \mathrm{cm}^{2}\right)\end{array}$ & Ref. \\
\hline $\mathrm{X} 70$ & - & -817 & - & [4] \\
\hline $\mathrm{X} 70$ & - & -550 & - & [5] \\
\hline $\mathrm{X} 70$ & - & -200 & - & [7] \\
\hline X60 & 0.00019 & -951 & - & [9] \\
\hline X60 & 0.00024 & -817 & - & [9] \\
\hline X60 & 0.0029 & -1081 & - & [9] \\
\hline $\mathrm{X} 52$ & 0.15 & -826 & 1107 & [11] \\
\hline X60 & 0.18 & -831 & 1159 & [11] \\
\hline X65 & 0.50 & -735 & 693 & [11] \\
\hline $\mathrm{X} 70$ & 0.16 & -841 & 1042 & [11] \\
\hline X80 & 0.28 & -821 & 1090 & [11] \\
\hline $\mathrm{X} 52$ & $0.025 / 0.079$ & $-583 /-955$ & $17,703 / 11,108$ & [11] \\
\hline X52 & $0.13 / 0.18$ & $-315 /-1000$ & $2146 / 3728$ & [11] \\
\hline $\mathrm{X} 52$ & $0.22 / 0.38$ & $-817 /-949$ & $1886 / 2659$ & [11] \\
\hline $\mathrm{X} 70$ & - & $-905 /-995$ & - & [14] \\
\hline X80 & $2.32 / 4.64$ & $-665 /-695$ & $34 / 35$ & [15] \\
\hline $\mathrm{X} 70$ & 0.01 & -464 & 10,409 & [16] \\
\hline X80 & - & -775 & - & [17] \\
\hline X80 & - & -775 & - & [18] \\
\hline $\mathrm{X} 52$ & - & -875 & - & [19] \\
\hline X80 & - & - & 12,000 & [23] \\
\hline $\mathrm{X} 70$ & - & -875 & - & [163] \\
\hline $\mathrm{X} 70$ & - & -835 & 1700 & [164] \\
\hline X100 & - & - & $2742 / 2843$ & [198] \\
\hline
\end{tabular}


Table 6. Continued reviewed electrochemical properties for external corrosion studies.

\begin{tabular}{|c|c|c|c|c|}
\hline Steel & $\begin{array}{l}\text { Corrosion Rate, } \\
\text { CR (mm/Year) }\end{array}$ & $\begin{array}{l}\text { Corrosion Potential, } \mathrm{E}_{\mathrm{corr}} \\
\left.(\mathrm{mV} \text { vs. } \mathrm{Cu} / \mathrm{CuSO})_{4}\right)\end{array}$ & $\begin{array}{c}\text { Charge Transfer } \\
\text { Resistance, } R_{c t}\left(\Omega \cdot \mathrm{cm}^{2}\right)\end{array}$ & Ref. \\
\hline X70 & - & $-850 /-1075$ & $909 / 3791$ & [24] \\
\hline X80 & 0.006 & -835 & 40,000 & [36] \\
\hline X80 & - & - & $966 / 2600$ & [124] \\
\hline $\mathrm{X} 70$ & - & -675 & - & [133] \\
\hline X52 & - & -960 & - & [159] \\
\hline X70 & - & -825 & $500 / 600$ & [162] \\
\hline X70 & 0.9 & -947 & 2300 & [165] \\
\hline X70 & - & - & $153 / 215$ & [201] \\
\hline X80 & - & -1075 & - & [202] \\
\hline S235JR & $0.02 / 0.2$ & -675 & - & [203] \\
\hline
\end{tabular}

According to Tables 2 and 3, some coating types such as FBE, PMMA, PE, and viscoelastic polymer in the absence and in the presence of damage were used to study the external corrosion process $[4-7,9,124]$. Simulated soil solutions containing carbonate compounds were more documented than the natural soil. The reviewed $\mathrm{pH}$ values were about acidic, neutral, and alkaline media (4.0 to 9.6). Moisture content values were around 1.5 to $52.3 \mathrm{wt} \%$ for some soil types, while the redox potentials were about 50 to $373 \mathrm{mV}$ vs. $\mathrm{Ag} / \mathrm{AgCl}$ electrode.

Regarding the mechanical properties, Table 4 showed the YS, UTS, elongation (E), and elongation plastic (EL) which are related to SCC. They may be determined using NACE Standard TM0198 and ASTM Standard G129, respectively [44,53]. In some cases, different heat treatments for X70 steel were studied, the elongated alternating grains of pearlite and ferrite phases and the presence of inclusions were reported elsewhere, microcracks and energy dispersive spectroscopy (EDS) analysis were analyzed, and micrograph for fracture and calculation of crack and toughness propagation rate were documented $[18,19,21,22]$. In the case of mechanical tests, a strain speed (v) of $1 \times 10^{-6} \mathrm{~s}^{-1}$ is accepted as typically strain rate for SCC characterization by using slow strain rate tests $[8,44,53]$. Tables 5 and 6 show that poor corrosion rate $(C R)$ and charge transfer resistance $\left(R_{c t}\right)$ data were obtained. However, CR values were around 0.001 to $4.64 \mathrm{~mm} / \mathrm{year}$ depending on the electrolyte. As regards the brief experimental summary, exposure time, scanning electron microscopy (SEM) examination and hardness Vickers (HV) for X60 (201 HV) and X65 (221 to $288 \mathrm{HV}$ ) steel exposed to synthetic soil solution were reviewed [8,160]. A uniaxial elastic stress study of X100 steel immersed in a near $\mathrm{pH}$ medium was published elsewhere [198]. This study concluded that not fracture during loading where the critical failure strain around 0.00357-0.00417 was reached. In addition, a special cell arrangement for electrochemical studies and SSRT was reported earlier [199]. Thus, a natural soil containing corrosive ions, organic content $(22,600 \mathrm{mg} / \mathrm{kg}$ soil), whole nitrogen content $(910 \mathrm{mg} / \mathrm{kg}$ soil) and total salt content (464 mg/kg soil) were analyzed [199]. It revealed that the stresses and the presence of sulfate-reducing bacteria (SRB) enhanced the SCC susceptibility on steel surface. Wu et al. [200] reported the mechano-chemical study for pipeline steel immersed in a special solution showing a microbiological corrosion by SRB related to the Desulfovibrio desulfuricans. The authors concluded that different micro-voids-cracks should be preconditioned in certain stages from the mechanic-chemical study (tensile load applications). It was published earlier [200] that the interaction between SRB behavior and strain growth rate could not be correlated. A microbiological corrosion study for pipeline steel exposed to soil and under yield stress was reported in a previous work [99]. In this case, SRB and culture solution with $\mathrm{pH}$ around 7.0 to 7.2 were selected. Fu and Cheng [4] reported different test solutions containing different carbonate-bicarbonate concentrations with $\mathrm{pH}$ and conductivity around 9.4-9.6, and 21.8-61.5 mS/cm, respectively, in order to tests the electrochemical and SCC behavior for X70 steel with a disbonded coating. The authors concluded that the steel could be passivated, and an active-passive transition may occur. Additionally, these authors reported that the corrosion potential of the steel was shifted toward negative values, and the current density increased 
using the cathodic protection test, and the stress enhanced as well. In some prepared solution such as NS4 near-neutral pH value containing bicarbonates, chloride compounds and sulfate has been reported [201]. In this study, corrosion under deposits affected by cathodic and anodic reactions for X70 steel was analyzed. Experimental data revealed that the deposit formed on steel surface was porous and non-compact in nature inhibiting the absorption and permeation of hydrogen. SCC could start from the pits and dissolution sites that must be formed underneath the oxides films. However, the deposit increased the corrosion effect. Other work [202], carbonate-bicarbonate media, various solutions were proposed to SCC characterizations: $0.5 \mathrm{M} \mathrm{Na}_{2} \mathrm{CO}_{3}+1 \mathrm{M} \mathrm{NaHCO}_{3} \mathrm{pH}=9.32$. Electrochemical results suggested that in the absence of alternating current cracks propagation was intergranular and the SCC mechanism was attributed to the anodic dissolution [202]. While, trans-granular cracks were obtained in the presence of alternating current. These mechanisms were attributed to the alkaline $\mathrm{pH}$ value, dissolution and hydrogen embrittlement behavior. In another study, sodium-carbonate solutions was used to assess the corrosion process for a stressed section cut from U-bend X70 steel specimen [162]. It concluded that pitting effects and cracks initiation occurred by the deformation-induced stress in alkaline medium. Carbonate compounds had an inhibitive behavior at low deformation-induced stress blocking the stressed zones. In addition, tensile stress increased the metal dissolution more considerably than compressive stress, resulting in more calcareous compounds.

The original mechanical character of the steel is an important parameter in the SCC mechanism. Thus, the original properties could be diminished when pipeline steels are exposed to corrosive environments, and a stronger interaction with the electrolyte type and its concentration, $\mathrm{pH}$ value, hydrodynamic condition, temperature, and gas pressure) may occur. Thus, the external corrosion damage initiation may be expected on susceptible anodic sites $[9,11]$. That is because different damage of the microstructure, and electrochemical responses of the cracked tip exposed to natural soil or simulated soil solution can be obtained $[8,160]$. On the other hand, external corrosion studies were developed using high anodic polarization or microbiological effects [162,164,200,202]. In a work, different working electrodes of a ruptured pipeline during 19 years of being buried in near-neutral-pH solution (since 1980 up 1999) were used [161]. Moreover, different external crack depth and crack width for external SCC on carbon steels were reviewed. Microcracks, secondary cracks, and crack growth must be expected as well [160,164,172,198-201], crack initiation [162], sharp intergranular cracks and anodic dissolution crack [159], cracks initiation [165], shallow cracks [124], intergranular cracks at elevated temperatures [32], intergranular, and trans-granular cracks narrow and shallow cracks [14,23,199,202], "linked" and parallel cracks [161] for external corrosion were reviewed.

The reviewed electrochemical tests included three-electrode set up and different geometries of the working electrode such as flat tensile specimens, sheet specimens, rod specimens, U-bend steel specimen. Preliminary conclusion from external SCC suggested that microstructure of the carbon steels, coating type, $\mathrm{pH}$ value, redox potential, and moisture content simulating the stages of season of the year, electrolyte type from each soil type are a really important parameters affecting the cathodic potential variations and the possible hydrogen evolution in underground pipelines under dry and rainy conditions. Some studies related to the integrity approach (stochastic and Bayesian models) by semi empirical or theoretical modeling for low carbon steels exposed to soil have been documented [183-186,190]. However, no external SCC model was reported. Additionally, all the above did not include the social problems where corrosion failures in pipelines are attributed to illegal tapping.

In field scenarios from buried pipelines in México, and in accordance with the standard recommended practices for complementary external SCC studies, some determined parameters include: moisture values up to $50 \mathrm{wt} \%, \mathrm{pH}$ around 4.0 to 9.0 , mass loss up to $20 \%$, exposure time up to 40 years, coated pipelines (up to 36 years), range of temperature about $65{ }^{\circ} \mathrm{C}$, ultimate tensile strength (UTS around 500 to $900 \mathrm{MPa}$ ), yielding strength (YS around 396 to $600 \mathrm{MPa}$ ), potential around $-850 \mathrm{mV}$ vs. $\mathrm{Cu} / \mathrm{CuSO}_{4}$ for buried pipelines, $950 \mathrm{mV}$ vs. $\mathrm{Ag} / \mathrm{AgCl}$ for seabed (submarine) pipelines, and redox potential about $600 \mathrm{mV}$ vs. $\mathrm{Ag} / \mathrm{AgCl}$ could be achieved in pipeline exposed to natural 
soils where seasonal fluctuations is expected [11,92]. Concerning biological parameters (biocorrosion), the microorganisms affecting the SCC phenomena are related to SRB, sulfur-sulfide oxidizing bacteria (SOB), iron-oxidizing bacteria (IOB), iron reducing bacteria (IRB), organic acid-producing bacteria, and acid-producing fungi as was reported by Cheng [1]. In the oil field, the term bacteria is related to a biofilm formation causing negative effects [204]. Concerning SRB this is an anaerobic microorganism which is able to reduce sulphates toward sulfides producing hydrogen sulfide $\left(\mathrm{H}_{2} \mathrm{~S}\right)$ at 25 to $50{ }^{\circ} \mathrm{C}$, and it is commonly found in internal pipelines up to $60^{\circ} \mathrm{C}$ and high salinity (produced water, connate water or brine water) $[205,206]$. SOB and IOB are aerobic microorganisms. IRB can produce $\mathrm{Fe}^{3+}$ corrosion $^{3}$ products (rust) and is able to form anaerobic zones to favor the growth of biofilm by SRB when both bacteria are interacted $[34,205,206]$. The corrosion occurs along the localized sites of the metal where induced product from the adsorption, growth, division, metabolic waste, and decomposition is caused by the bacteria to conduct other forms of corrosion such as corrosion under deposit, pitting, crevice, galvanic, and intergranular deterioration [34].

\section{Parameters Reported in the Literature Regarding Internal SCC}

Table 7 shows some internal environments affecting operating pipelines to develop SCC. Clearly, the environments (physicochemical, mechanical, electrical, and biological) of operating pipelines, include the quality of the hydrocarbon such as API gravity of hydrocarbons, oil viscosity, oil density, $\mathrm{pH}$ of the oilfield produced water (water cut), types of electrolyte into the oilfield produced water, as well as the operating pipeline conditions, mechanical behavior attributed to tribology (friction, wear, lubrication, and erosion), electrical, and biological parameters.

Table 7. Main internal environments affecting operating pipelines to develop SCC.

\begin{tabular}{|c|c|c|c|c|c|c|c|}
\hline $\begin{array}{c}\text { Factors } \\
\text { Electrical }\end{array}$ & \multicolumn{6}{|c|}{ Parameters } & $\begin{array}{l}\text { Ref. } \\
{[43]}\end{array}$ \\
\hline Physical & Oil API ${ }^{\circ}$ & Oil viscosity & Oil density & $\begin{array}{l}\text { Pressure, } \\
\text { temperature }\end{array}$ & Volumetric flow & Sediments & [194] \\
\hline Chemical & $\mathrm{pH}$ & $\begin{array}{l}\text { Water cut, water } \\
\text { associated with } \\
\text { hydrocarbons }\end{array}$ & $\mathrm{CO}_{2}, \mathrm{O}_{2}$ & $\begin{array}{c}\text { Organic acid, } \\
\mathrm{H}_{2} \mathrm{~S}, \mathrm{H}_{2}\end{array}$ & Metals & Sulfates & [194] \\
\hline Biological & Bacteria & $\begin{array}{l}\text { Desulfobac } \\
\text { Desulfovibr }\end{array}$ & $\begin{array}{l}\text { ales } \\
\text { nales }\end{array}$ & SRB & $\begin{array}{l}\text { Acid producing } \\
\text { bacteria }\end{array}$ & - & {$[1,197,205,206]$} \\
\hline
\end{tabular}

Note: Oil $\mathrm{API}^{\circ}$ is the API gravity of hydrocarbons (in degrees).

Moreover, a review of the physicochemical, mechanical, and electrochemical variables studied and reported earlier are related to the I-SCC of carbon steel pipelines were carried out. The experimental part based on the physicochemical, mechanical, and electrochemical parameters affecting the internal corrosion were listed in Tables 8-10 [37,38,208-216].

Table 8. Reviewed physicochemical properties for internal corrosion studies.

\begin{tabular}{|c|c|c|c|c|}
\hline Steel & Electrolyte & $\mathrm{pH}$ & $\mathrm{T}\left({ }^{\circ} \mathrm{C}\right)$ & Ref. \\
\hline $\mathrm{X} 80$ & $\begin{array}{c}0.1 \mathrm{M} \mathrm{Na}_{2} \mathrm{SO}_{4}+\mathrm{CO}_{2} \\
0.1 \mathrm{M} \mathrm{NaHCO}_{3}+0.17 \mathrm{M} \mathrm{NaCl}\end{array}$ & $4.2 / 8.4$ & 25 & [37] \\
\hline Inconel 625/X60 & NACE Standard TM0177 test solution A & - & - & [38] \\
\hline $\mathrm{X} 52$ & $1 \mathrm{M} \mathrm{H}_{2} \mathrm{SO}_{4}$ & - & - & [208] \\
\hline Fe-C alloy & $8.5 \mathrm{M} \mathrm{NaOH}$ & 13.2 & 100 & [209] \\
\hline $\mathrm{X} 70$ & $3 \% \mathrm{NaCl}+\mathrm{H}_{2}(1.5-2.5 \mathrm{ppm})$ & - & $4 / 80$ & [210] \\
\hline $\begin{array}{l}X 52 \\
X 65 \\
X 70\end{array}$ & $\begin{array}{l}\text { NACE Standard TM0284; } \\
\text { NACE Standard TM0177 }\end{array}$ & $3.4 / 5.4$ & 200 & [211] \\
\hline
\end{tabular}


Table 8. Cont.

\begin{tabular}{|c|c|c|c|c|}
\hline Steel & Electrolyte & $\mathrm{pH}$ & $\mathrm{T}\left({ }^{\circ} \mathrm{C}\right)$ & Ref. \\
\hline X70 & 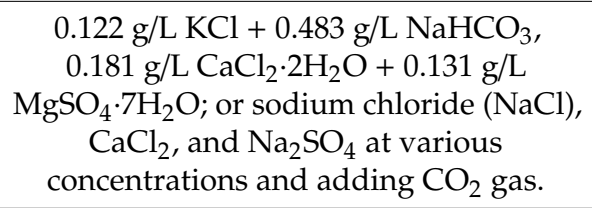 & $6.5 / 11.9$ & $20 / 40$ & [212] \\
\hline X65 & $\begin{array}{l}\text { 200-proof ethanol, anhydrous methanol, } \\
\text { glacial acetic acid and nano-pure } \\
\text { deionized water. }\end{array}$ & 7.6/7.7 & - & [213] \\
\hline X70 & $\begin{array}{l}\text { Dilute brine bubbled with } 10 \% \mathrm{CO}_{2} \text { and } \\
\text { dilute brine with } 1 \% \mathrm{H}_{2} \mathrm{~S}\end{array}$ & 4.9 & 30 & [214] \\
\hline X65 & $\begin{array}{c}3.5 \text { wt } \% \mathrm{NaCl} \text { with different } \\
\mathrm{H}_{2} \mathrm{~S}: \mathrm{CO}_{2} \text { gas ratios added }\end{array}$ & $3.8 / 4.4$ & $30 / 80$ & [215] \\
\hline X70 & $\begin{array}{c}1 \mathrm{~N} \text { Sodium carbonate plus } 1 \mathrm{~N} \\
\text { Sodium bicarbonate }\end{array}$ & - & 75 & [216] \\
\hline
\end{tabular}

Table 9. Reviewed mechanical properties for internal corrosion studies.

\begin{tabular}{ccccc}
\hline Steel & YS (MPa) & UTS (MPa) & EL (\%) & Ref. \\
\hline X60 & $468 / 499$ & $703 / 520$ & - & {$[38]$} \\
X70 & 812 & 1050 & - & {$[210]$} \\
X52 & 431 & 480 & 40 & {$[211]$} \\
X65 & 490 & 587 & 33 & {$[211]$} \\
X70 & 539 & 666 & 28 & {$[211]$} \\
X65 & 690 & 810 & - & {$[213]$} \\
X70 & 510 & 580 & 36 & {$[216]$} \\
\hline
\end{tabular}

Table 10. Reviewed electrochemical properties for internal corrosion studies.

\begin{tabular}{ccccc}
\hline Steel & $\begin{array}{c}\text { Corrosion Rate, } \\
\text { CR }(\mathbf{m m} / \text { Year })\end{array}$ & $\begin{array}{c}\text { Corrosion Potential, } \\
\mathbf{E}_{\text {corr }}(\mathbf{m} \text { V vs. SCE) }\end{array}$ & $\begin{array}{c}\text { Charge Transfer } \\
\text { Resistance, } \mathbf{R}_{\mathbf{c t}}\left(\boldsymbol{\Omega} \cdot \mathbf{c m}^{\mathbf{2}}\right)\end{array}$ & Ref. \\
\hline X80 & $1.75 / 0.014$ & $-660 /-634$ & 3000 & {$[37]$} \\
X60 & $0.01 / 0.69$ & - & - & {$[38]$} \\
X65 & $0.5 / 2.0$ & $-864 /-784$ & - & {$[200]$} \\
Fe-C alloy & $0.81 / 1.27$ & - & - & {$[209]$} \\
X52 & 98.5 & -680 & - & {$[211]$} \\
X65 & 121.7 & -680 & - & {$[211]$} \\
X70 & 127.5 & -690 & - & {$[212]$} \\
X70 & - & $-600 /-700$ & - & {$[216]$} \\
X70 & - & -650 & & - \\
\hline
\end{tabular}

Table 8 shows the physicochemical features of representative solution simulating electrolytes commonly found in internal pipelines. The reviewed $\mathrm{pH}$ values were around 3.4 to 11.9 and depending on the electrolyte type. As regards mechanical properties, Table 9 shows that the yield stresses were about 431 to $690 \mathrm{MPa}$, and the ultimate tensile strength of 480 to $1050 \mathrm{MPa}$ were obtained. Table 10 showed that $C R$ was around 0.01 to 98.5 for different metals, and the corrosion potential ( $E_{\text {corr }}$ ) was around -600 to $-864 \mathrm{mV}$ referred to saturated calomel electrode (SCE). While poor $\mathrm{R}_{\mathrm{ct}}$ values were obtained. Additionally, corrosion inhibition of X52 steel exposed to sulfuric acid containing different concentration of four corrosion inhibitors was studied [208]. In another study, CR values obtained for X80 steel exposed to sodium sulphate containing $\mathrm{CO}_{2}$ gas (Table 10) were calculated by the corrosion current density reported in a previous work [37]. CR values obtained for X80 steel exposed to $\mathrm{NaOH}$ at $100{ }^{\circ} \mathrm{C}$ (Table 10) were calculated by the corrosion current density reported elsewhere [209]. In another study, CR values obtained for X60 steel and Inconel 625 alloy both exposed to NACE test solution were 
determined by using weight loss tests [38]. $\mathrm{E}_{\mathrm{corr}}$ values obtained for $\mathrm{X} 65$ exposed to $3.5 \mathrm{wt} \% \mathrm{NaCl}$ containing different $\mathrm{H}_{2} \mathrm{~S}-\mathrm{CO}_{2}$ gas ratio were around -670 to $-590 \mathrm{mV}$ referred to $\mathrm{Ag} / \mathrm{AgCl}$ reference electrode [215]. An investigation related to heat affected zone (HAZ) for X70 steel different base metal and weld metal was reported [210]. In another study, four API steel grades were tested using a recommended solution from NACE Standard TM0284-2016 during $96 \mathrm{~h}$ prior to constant elongation rate tests with a strain rate of $0.003 \mathrm{~mm} / \mathrm{min}$ [211]. Thus, susceptibility to SSC and HIC were studied. Other test solutions used for the constant elongation rate test may be prepared according to NACE Standard medium.

The inhibition of X52 steel exposed to $1 \mathrm{M} \mathrm{H}_{2} \mathrm{SO}_{4}$ was investigated by Morales et al. [208]. In this work, an optimal corrosion inhibitor concentration, and a maximum inhibiting efficiency were obtained. In another work, the heating-cooling cycles on simulated weld heat affected zones for X80 steel exposed to chloride, bicarbonate, and $\mathrm{CO}_{2}$ solutions at different $\mathrm{pH}$ were reported [37]. Moreover, SCC of various carbon alloys exposed to alkaline $\left(8.5 \mathrm{M} \mathrm{NaOH}\right.$ at $\mathrm{pH} 13.2$ and $\left.100{ }^{\circ} \mathrm{C}\right)$ solution was studied, too [209]. This investigation concluded that susceptibility to caustic SCC was attributed to carbon element, and oxidation effects; but small beneficial effects was obtained when titanium was added into grain boundaries inhibiting the formation of magnetite $\left(\mathrm{Fe}_{3} \mathrm{O}_{4}\right)$. A representative test solution was prepared in order to study the trans-granular SCC on X70 steel exposed to carbon dioxide-containing ground water type $\mathrm{A}$ [212]. The solution was used to study the $\mathrm{CO}_{2}$ to $\mathrm{HCO}_{3}{ }^{-}$ and/or $\mathrm{CO}_{3}{ }^{2-}$ effect attributed to $\mathrm{pH}$ changes [212]. Regarding the electrolyte used to re-passivation tests of X65 steel exposed to fuel grade ethanol, a specific solution was prepared from three baseline test environment [213]. One of them contained $1.0 \mathrm{vol} \%$ water, $0.5 \mathrm{wt} \%$ methane, $56 \mathrm{mg} / \mathrm{L}$ acid acetic and balance with 200 proof ethanol reaching $\mathrm{pH}=5.6$. The others contained different amount of chloride in part per billion ( $\mathrm{ppb}$ ) reaching $\mathrm{pH}$ around 7.6-7.7. Their calculated resistivity values were around $0.5-40 \mathrm{k} \Omega-\mathrm{cm}$, and they depended on its type and concentration fuel grade ethanol. In another work, the crack advance for X70 steel based on stress corrosion cracking and fatigue was analyzed using the test rig clevises [214]. X70 steel was placed in an autoclave with $4.5 \mathrm{~L}$ of total fluid at $30^{\circ} \mathrm{C}$. Different cycles were used to simulate the stress cycles for detecting crack growth, and an initial test for X70 steel was carried out using maximum stress intensity factor (K) and $20 \mathrm{~Hz}$ [214]. To evaluate the electrochemical behavior for $\mathrm{X} 65$ steel exposed to $3.5 \mathrm{wt} \% \mathrm{NaCl}$ containing different $\mathrm{H}_{2} \mathrm{~S}-\mathrm{CO}_{2}$ ratio, Pessu et al. [215] used Tafel plots. It concluded that different mechanisms of $\mathrm{H}_{2} \mathrm{~S}-\mathrm{CO}_{2}$ corrosion were affected by temperature. It is important to point out that different crack depth and crack width for internal SCC on carbon steels were reviewed. Thus, secondary cleavage cracks, nucleated cracks, intergranular cracks, stress corrosion cracks, longitudinally orientated cracks and shallow cracks, circumferential cracks, stress corrosion cracks, deepest cracks, orientated cracks, interdendritic and secondary cracks, shallow cracks, yielding stress corrosion, small and large cracks, yielding stress corrosion cracks, and stress corrosion cracks, propagated cracks, secondary cracks, cracks propagated trans-granularly were studied and reported in the literature [38,39,208,211-213,215-221]. Moreover, mechanical properties for carbon steels can be affected by the hydrogen presence causing cracks on external pipeline surfaces by HIC $[159,222]$. The reviewed internal corrosion data showed that there are some models to predict the corrosion damage and determining of the remaining strength of corroded surfaces in an operating pipeline according to values of parameters such as operating pressure and temperature, gas flow, and the corrosiveness of the electrolyte; however, internal SCC is not considered. Erosion, generalized, and localized (pitting) corrosion are only allowed to the empirical and theoretical internal corrosion models. However, why is in-line inspection (ILI) technology an important tool in operating pipelines? Because ILI (magnetic flux leakage, pipeline pig) technology is a project objective for identifying and characterizing pipelines features such as anomalies, indications, defects, or integrity threats $[97,172,223,224]$. Thus, development of protocols from data integration and evaluation is highlighted. Then, a report of the integrity assessment scenarios (crack modeling, metal loss, and technical recommendation to carry out the inspection from failure analysis diagram) and prioritization (features and selected sites to excavate and repair) is conferred [191]. However, 
hydrostatic pressure testing (proof of service), long-range ultrasonic testing (LRUT), guided wave technology (GWT), automated ultrasonic testing (AUT), and manual ultrasonic testing (UT) are other technologies to support the evaluation of ILI technology given a complete scenario of the damaged or corroded surfaces of the pipelines [97,223]. Internal corrosion models are commonly applied to analyze the parabolic profile of mechanical and corrosion damage, regression analysis, holistic analysis, and mechanistic models based on remaining life of pipeline systems, among other data. Internal corrosion is attributed to pressure and temperature concerning the flowrate in thousands of barrels per day (TBD). However, internal pipe wall thickness is commonly affected by different SCC mechanisms. Therefore, hydrogen and $\mathrm{CO}_{2}(\mathrm{pH}<7.0)$ are two main electrolytes promoting internal SCC $[27,215]$.

After a brief review, it is possible to note that the internal SCC phenomena could be affected by the hydrogen source that comes from sour media or brine sour media (hydrogen sulfide, and carbon dioxide), hydrochloric acid, sulfuric acid, sodium hydroxide, organic acids, internal bacteria induced corrosion, cathodic polarization, and by the over-operating pressure, and elevated temperature. Internal corrosion damage for pipeline steels has been analyzed using several corrosion models, numerical data, different mathematical modeling strategies such as hypotheses models and theories $[169,223,225,226]$, historical data and internal corrosion inspection data of the pipeline [96,97], acquired code from artificial neural networks which are used for a non-lineal corrosion rate prediction model as well as to weigh and refine the influencing factors using Grey relational analysis methods [169]. Additionally, top-of-line corrosion models [169], stochastic models, power or exponent law (empirical or semi-empirical models), Bayesian analysis, statistical models and mechanistic models or electrochemical reactions [184,227-232] have been used. In field practices, the operating pipelines are exposed to different internal variables, which in turn means they react in many ways, as shown in Table 7. Thus, internal SCC could be attributed to field sludge (fouling tendency influence) plugging the transport process of the hydrocarbons and increasing the pressure gradient (pressure drop). This problem is increased when an incorrect operating pressure (overpressure) may occur and more flow in thousands of barrels per day (TBD) of the hydrocarbon is transported through pipelines [13]. For that reason, safety operating pressure must be considered during the production, gathering, storage, and transportation of hydrocarbons through pipelines. It is known that the internal corrosion starts from brine environment, water cut (oilfield produced water, or liquid holdup), and more corrosive emulsions [12]. The internal wall of the pipeline steels and storage tanks exposed to brine reservoir can be affected by corrosive gases including hydrogen element, high salt concentrations, solids, metals, and pressure effects [96,97]. In this way, pipeline steels transporting crude oil, condensed hydrocarbons, refined hydrocarbons, natural dry gases and natural wet gases could have different corrosive media such as oxygen, carbon dioxide $\left(\mathrm{CO}_{2}\right)$, carbonic acid $\left(\mathrm{H}_{2} \mathrm{CO}_{3}\right)$, hydrogen sulfide $\left(\mathrm{H}_{2} \mathrm{~S}\right)$, naphthenic acid, water cut, salts content, physicochemical properties, organic acids, among other data [12,13,44,97,169]. As the direct contact between the internal steel surface and fluid (refined hydrocarbons, oil, produced water, wet gas, dry gas, and field sludge) take place, it is interesting to research the interplay between them and the resulting corrosion initiation and propagation such as pitting. That is because pipeline internal wall are always in a susceptibility stage. It means that the propagation of the generalized and localized (pitting) corrosion damage could be affected by the internal SCC and defects (indications).

There are some standard practices that simulate the corrosive medium which is related to crude oil, dry and wet gas for internal corrosion studies [44,96,97]. A recommended standard test for SCC study is NACE Standard TM0198 [44]. In addition, different mixtures of saline water solution containing dissolved $\mathrm{CO}_{2}$, acid gasses $\left(\mathrm{H}_{2} \mathrm{~S}\right)$, acetic acid, and oxygen may be prepared at laboratory level as sour environment for promoting hydrogen and $\mathrm{CO}_{2}$ gas for deterioration investigation [97,166]. Some physicochemical, mechanical, and electrochemical properties that have been reported to simulate the internal corrosion process and SCC for low carbon steels, mainly [27,37,38,208-216]. Because hydrogen gas comes from the external and internal sources, the SCC pipeline steels is an important topic which needs to be researched considering the electrolytically hydrogen charged on steel surfaces using cathodic potential. In this way, internal corrosion process can 
be studied where the hydrogen related degradation is highlighted using cathodic polarization [210]. However, for carbon steel corroded surfaces, the interpretation of measurements is largely restricted to elemental/chemical fingerprinting. It should be a topic of great academic and industrial interest after an experimental revision.

In field practices from oil pipelines in México, the physicochemical parameters are obtained from direct and indirect assessment, in accordance with the standard recommended practices for complementary internal SCC studies, resulting in oil $\mathrm{API}^{\circ}$ around $4^{\circ}$ to $22^{\circ}$, temperatures around $20^{\circ} \mathrm{C}$ to $180{ }^{\circ} \mathrm{C}$, oil viscosity around $0.105 \mathrm{~kg} / \mathrm{ms}$, oil density from $820 \mathrm{~kg} / \mathrm{cm}^{3}$ to $920 \mathrm{~kg} / \mathrm{cm}^{3}$, pressure around $20 \mathrm{~kg} / \mathrm{cm}^{2}$ to $70 \mathrm{~kg} / \mathrm{cm}^{2}\left(284 \mathrm{lb} / \mathrm{in}^{2}\right.$ to $\left.995 \mathrm{lb} / \mathrm{in}^{2}\right)$, volumetric flow about $0.441 \mathrm{~m}^{3} / \mathrm{s}$, sediments about $0.11 \mathrm{wt} \%$ (0.5 wt \% maximum), velocity from 0.5 to $11 \mathrm{mph}(0.22 \mathrm{~m} / \mathrm{s}$ to $4.9 \mathrm{~m} / \mathrm{s}), \mathrm{pH}$ around 4 to 11 , water cut around $20 \%$ volume to $70 \%$ volume, water in hydrocarbon $0.1 \%$ volume $(0.5 \%$ volume maximum), $\mathrm{H}_{2}, \mathrm{CO}_{2}, \mathrm{O}_{2}$ around $10,000 \mathrm{ppb}$, organic acid about $0.75 \mathrm{mg} \mathrm{KOH} / \mathrm{g}(0.28$ maximum), $\mathrm{H}_{2} \mathrm{~S}$ about 10,000 ppm, metals about 300 ppm, sulphates about 1688 ppm, chlorides (up to 60,000 ppm), $\mathrm{Fe}^{2+}$ (up to $100 \mathrm{ppm}$ ), hydrocarbon quality, chemical treatments (up to $125 \mathrm{ppm}$ dosage), salt content about 57 pounds/1000 barrels per day (50 pounds/1000 barrels per day maximum), mass loss (up to $33 \mathrm{wt} \%$ ), different types of emulsions, metal such as vanadium about 253 ppm (270 ppm maximum). In the case of mechanical properties, YS around 396 to $600 \mathrm{MPa}$, and UTS around 500 to $900 \mathrm{MPa}$ may be achieved. In microbiological properties, aerobes, facultative, and anaerobes could be assessed, as well as Desulfobacterales, Desulfovibrionales, and Desulfuromonadales, and other sulphate reducing bacteria (SRB, such as Clostridia), Fe (III) reducing bacteria and acid producing bacteria also could be highlighted $[205,206]$.

\section{Comparison of Parameters Studied and Reported in the Literature}

For the purpose of the comparison, some figures were made using data acquired from parameters studied and reported in the literature regarding the external and internal SCC of carbon steel pipelines, which were registered in Tables 2-6 for external properties, and Tables 8-10 for internal properties. As a result, Figures 4-6 were plotted and an analysis of the more representative external environments affecting operating pipelines to develop SCC was addressed $[4,6,7,11-13,17,37,210,211]$. Figure 4a shows the external parameters regarding physicochemical and electrochemical behavior $[4,7,11,17]$. According to this figure, it is possible to note that the moisture and redox potential values were about 22.5 to $52.3 \mathrm{wt} \%$ and 265 to $373 \mathrm{mV}$, respectively, which corresponded to near acidic to alkaline soil ( $\mathrm{pH}$ around 6.0 to 8.1). In addition, Figure $4 \mathrm{~b}$ shows that the natural corrosion potentials ( $\mathrm{E}_{\mathrm{corr}}$ values) for $\mathrm{X} 52, \mathrm{X70}, \mathrm{X} 80$, and $\mathrm{X} 100$ steels were around -400 to $-1300 \mathrm{mV}$ vs. $\mathrm{Cu} / \mathrm{CuSO} \mathrm{C}_{4}$ electrode, when $\mathrm{pH}$ value was near acidic to alkaline solution. The natural potentials obtained on $\mathrm{X} 70$ steel at different $\mathrm{pH}$ were more studied and documented than the rest of carbon steels. According to $\mathrm{pH}$, it is important to consider that how is the atomic hydrogen formed in the OD and how is it formed in the ID maybe the key in the similarities and differences between the external and internal cracking susceptibility, and it should be addressed. It is important to note that about the paper is it has a lot of corrosion science papers and few corrosion papers. Corrosion has many, perhaps superior publications, in this area on this topic (year: 1960-2015, total articles: 5530, SCC articles: 1050, SSRT articles: 370) [233]. However, in its current form, it seem that no external and internal SCC affected by the physicochemical, mechanical, and electrochemical data is highlighted, with particular interest in carbon steel pipelines transporting hydrocarbons. 

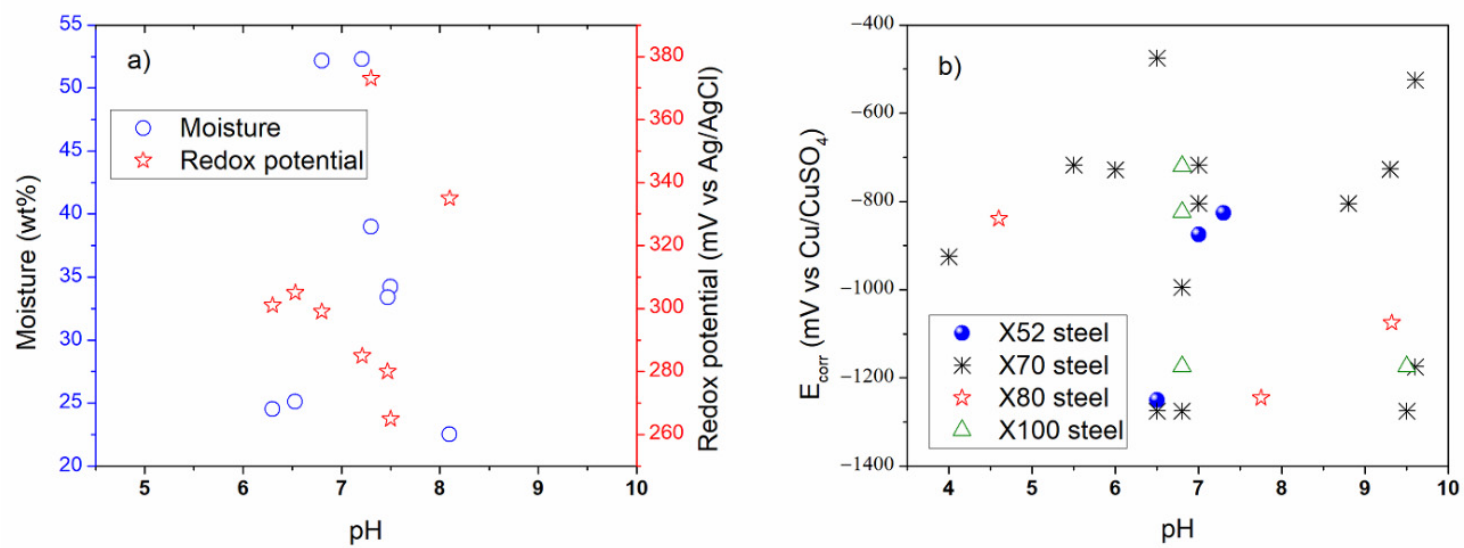

Figure 4. External corrosion analysis based on the reviewed (a) physicochemical properties, and (b) physicochemical and electrochemical properties.
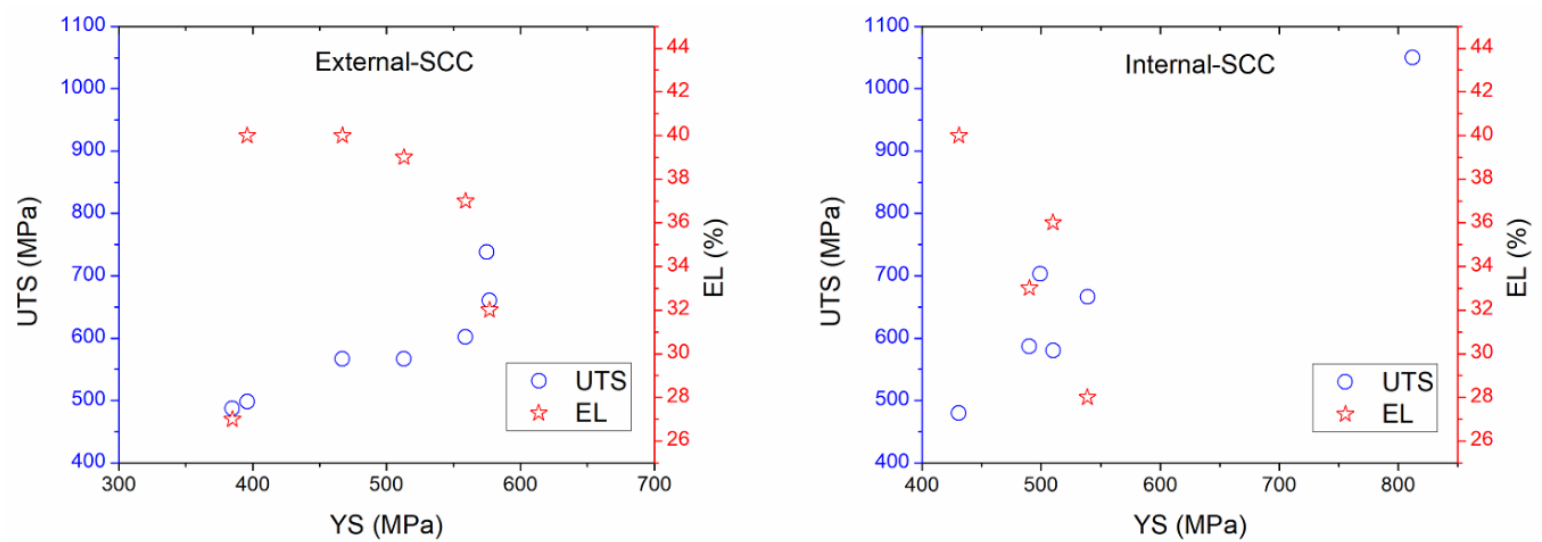

Figure 5. Comparison of the external- and internal-stress corrosion cracking ((E-SCC) and (I-SCC)) in respect to mechanical properties based on the reviewed experimental data.
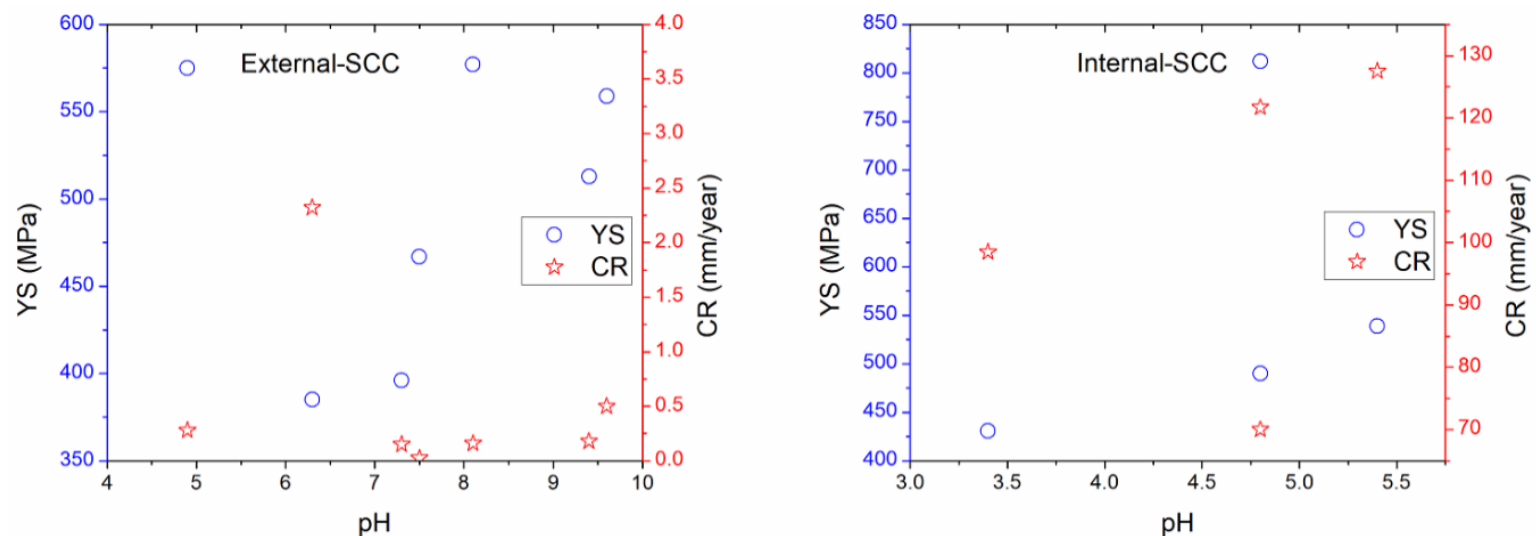

Figure 6. Comparison of the E-SCC and I-SCC behavior based on mechanical-electrochemicalphysicochemical properties.

Figure 5 suggests that the UTS values that concern the external parameters increased as YS is increased, too; while EL ranges from $27 \%$ to $40 \%$ were obtained, which corresponded to YS around 400 to $600 \mathrm{MPa}[4,7,11-13,37,210,211]$. As regards internal corrosion, UTS values were around 425 to $1050 \mathrm{MPa}$ when YS were about 430 up to $550 \mathrm{MPa}$, while EL values have been estimated as $28 \%$ to $44 \%$ in the range of YS from 430 up to $549 \mathrm{MPa}$. In addition, the external parameters related to UTS and EL versus YS were minor in comparison with those data obtained in the literature 
regarding internal SCC; indicating that more susceptibility to internal SCC could occur. In comparison with the mechanical-electrochemical-physicochemical parameters, Figure 6 shows that the $\mathrm{pH}$ in solution is an important parameter affecting the mechanical properties; which was lower for internal corrosion where atomic hydrogen production may occur $[4,7,11-13,17,37,210,211]$. Thus, acidic media or microorganisms must be the dominant internal factors to develop SCC affecting the operating pipelines. It is not surprising that pitting corrosion or active metal dissolution could be used to ensure the SCC occurrence toward high corrosion resulting in local cracks and severe localized corrosion of the internal pipeline. The presence of water on both sides (OD and ID) of the steel is the key reason for corrosion. However, the corrosion could be increased depending on the electrolyte type into the water. Thus, high corrosion rate attributed to significant mass loss is expected.

\section{Recommendations}

First, the topic of the reviewed manuscripts can be relevant and of great importance for parameters affecting the external and internal SCC; however, some recommendations are conferred:

\section{External SCC}

- Edaphology studies should be used to ensure a more mechanistic investigation, and a fundamental role during cathodic protection as a function of seasonal changes because natural media (growth and decomposition of plants).

- It is important to point out that, the original mechanical properties of the steel specimens exposed to soils could cause a reduction of the mechanical properties after electrochemical tests (carbon steels exposed to corrosive media).

- All of the assessment scenarios, the environments of operating pipelines including types of soils, moisture content, $\mathrm{pH}$, and redox potential have been characterized, but with some limitations related to prepared soil solutions. The change of environment in each type of soil should be removed or controlled by a suitable ore such as Zeolite.

- Corrosion rate studies on pipeline steels immersed in natural soil have become important in materials research in the electrochemical and geological fields, mainly.

- Take care of the cathodic protection systems applied from winter until the beginning of the dry season (spring) when the water content in soils begin to evaporate, as the level of the cathodic protection on pipelines exposed to different types of soils may change with the moisture content.

- In field conditions, soil type, $\mathrm{pH}$ and moisture content for natural soils are three important parameters that should be measured for possible external SCC in buried pipelines. This is because representative soil solutions will always offer saturated conditions; thus, they will not always simulate the natural modification of the water content in soils, and they depend on geographical site of the buried pipeline.

- $\quad$ SCC for API steels exposed to marine environments (seabed) should be studied.

- When a pipeline is designed, not only is it necessary to consider the internal fluid which is transported, but the external media concerning to SCC must also be considered.

\section{Internal SCC}

- The environments of operating pipelines (including types of extracted oilfield produced water, heavy and extra-heavy crude oil from oilfield, temperatures, and $\mathrm{pH}$, mainly) have been characterized, but with some limitations related to prepared electrolytes in accordance with standard recommended practices for internal SCC studies.

- In some cases, internal SCC could be activated by operating pressure and temperature during the production, gathering, storage and transportation of hydrocarbons through pipelines.

- Different manufactured steels with different exposure areas (geometrical areas) were reported. Therefore, mechanical-electrochemical mechanisms related to SCC depending on steel surface conditions where a specific active (anode-cathode) site are expected. 
- Small modifications of the physicochemical properties of the solution significantly could change the interactions between the active site of the steel and electroactive species.

- Weld heat affected zones in pipeline steels could cause severe modifications of the microstructure and possible SCC, and it depends on the internal electrolyte influenced.

- SCC damage such as oblique, circumferential, and not oblique/circumferential-neither oblique nor circumferential stacking of axial cracks should be considered in the laboratory. This is because these types of cracking can be found in the field.

- $\quad$ Studies about I-SCC must address the microstructure in each API steel grade.

- Complementary studies about I-SCC considering higher contents of $\mathrm{H}_{2} \mathrm{~S}$ in the electrolytes and high temperature and pressure are necessary.

\section{Conclusions}

In this work, an experimental review of innumerable scientific articles that concern external and internal SCC on carbon steels was documented, and some conclusions are headlined as a follow:

- To avoid E-SCC and I-SCC in carbon steels three important parameters are recommended: (1) removal or control of the corrosive electrolytes in each change of environment, (2) use a suitable carbon steel with high quality, and (3) select the appropriate physical (coating), electrochemical (cathodic protection), and chemical (biocide or corrosion inhibitor) treatment applications.

- The evolution of the knowledge on stress corrosion cracking was taken from the fatigue corrosion process.

- In oil and gas industry, the SCC, HIC, and SSC processes are attributed to hydrogen (proton) becoming corrosive gas, that comes from the combining external and internal environmental sources such as sulfide compounds, acidic soils, acidic atmospheric compounds, $\mathrm{HCl}, \mathrm{H}_{2} \mathrm{SO}_{4}$, $\mathrm{H}_{2} \mathrm{O}$, naphthenic acid, organic acids (acetic acid, mainly), among other data.

- Hydrogen entrance into the pipeline is the main cause of cracking and fracture, either from the outside diameter (OD) or the inside diameter (ID).

- The atomic hydrogen generated on both surfaces of the steel is the one that diffuses into the steel and may reduce its mechanical integrity by generating cracks.

- Corrosion damage for pipelines transporting hydrocarbons depends on the electrolyte type (internal and external) which is commonly found in a specific geological and geographical site.

- Not all evidence for electrolytes may be expected from experimental tests at laboratory level. This is because more physicochemical modifications could be expected in natural electrolytes.

- In some cases, external SCC could be initiated by atomic hydrogen that comes from over-voltage during cathodic protection process.

- External and internal SCC is stronger influenced by bicarbonates, $\mathrm{CO}_{2}$, carbonic acid $\left(\mathrm{H}_{2} \mathrm{CO}_{3}\right)$, and oxygen. However, the presence of water on both OD and ID of the steel is the role for corrosivity, susceptibility, and tensile stress on the E-SCC and I-SCC science. Therefore, oxygen, carbonates/bicarbonates concentrations, heavy metals, and sulfides and high strength are not important in the absence of water.

- Due to the production of corrosive microbial metabolites by different bacteria, it is important to carry out classical and molecular microbiological studies to determine, assess, and evaluate the type of microbial community found in the pipeline site. This information can be related to the chemical analysis of the soil—if an external corrosion has been determined in the SCC study—or to the fluid inside the pipeline-in the case of internal corrosion evaluation results being positive and the consequent evidence of the SCC phenomenon confirmed. Furthermore, it will depend upon the behaviors or electrochemical profiles that are carried out with the microorganisms detected in the site of the pipeline. 
- Different types of external SCC cracks were reviewed from previous works such as micro-cracks, sharp intergranular cracks, initiation of cracks, intergranular cracks, stress corrosion cracks, intergranular and trans-granular cracks narrow and shallow cracks, "linked" and parallel cracks.

- For the internal corrosion the following SCC cracks were reviewed: secondary cleavage cracks, nucleated cracks, intergranular cracks, longitudinally orientated cracks, shallow cracks, circumferential cracks, stress corrosion cracks, deepest cracks, orientated cracks, inter-dendritic cracks, shallow cracks, small and large cracks, yielding stress corrosion cracks, finger-like cracks emerging from pits, propagated cracks, propagated trans-granular cracks, and individual cracks.

Author Contributions: Conceptualization, methodology and formal analysis L.M.Q.-A.; investigation and data curation, Y.d.R.D.-A., I.A.A.-J., J.N.R.-O. and V.G.-F.; writing-original draft preparation, L.M.Q.-A.; writing-review and editing, L.M.Q.-A. and I.Z.-P.; supervision, and project administration, I.Z.-P.; funding acquisition, I.Z.-P. and J.N.R.-O. All authors have read and agreed to the published version of the manuscript.

Funding: This work was supported by the project no. D.61073 of the Instituto Mexicano del Petróleo, and the Project TECNM-8207.20-PD of the Tecnológico Nacional de México.

Acknowledgments: The authors gratefully acknowledge Olvera Martinez for her valuable support, feedback, and comments throughout the development of this work. The authors also thank the Laboratory of Electrochemical Testing of the Instituto Mexicano del Petróleo (IMP-México). R.-O.J.N. thanks to TESI and TECNM for financial support (Grant TECNM-8207.20-PD). A.-J.I.A. wishes to thank Consejo Nacional de Ciencia y Tecnología (CONACYT-México) for granting her PhD scholarship, as well as IMP-Postgraduate Program.

Conflicts of Interest: The authors declare that they have no conflict of interest.

\section{References}

1. Cheng, Y.F. Stress Corrosion Cracking of Pipelines, 1st ed.; John Wiley and Sons, Inc.: New York, NY, USA, 2013; pp. 7-115.

2. Logan, H.L. The Stress Corrosion of Metals, 1st ed.; John Wiley and Sons, Inc.: New York, NY, USA, 1967; pp. 1-43.

3. Beavers, J.A.; Thompson, N.G. External corrosion of oil and natural gas pipelines. In ASM Handbook; Cramer, S.D., Covino, B.S., Eds.; Corrosion: Environments and Industries (\#05145); ASM International: New York, NY, USA, 2006; Volume 13C, pp. 1015-1025.

4. Fu, A.Q.; Cheng, Y.F. Electrochemical polarization behavior of X70 steel in thin carbonate/bicarbonate solution layers trapped under a disbonded coating and its implication on pipeline SCC. Corros. Sci. 2010, 52, 2511-2518. [CrossRef]

5. Yan, M.; Wang, J.; Han, E.; Ke, W. Local environment under simulated disbonded coating on steel pipelines in soil solution. Corros. Sci. 2008, 50, 1331-1339. [CrossRef]

6. Fu, A.Q.; Cheng, Y.F. Characterization of corrosion of X65 pipeline steel under disbonded coating by scanning Kelvin probe. Corros. Sci. 2009, 51, 914-920. [CrossRef]

7. Fu, A.Q.; Tang, X.; Cheng, Y.F. Characterization of corrosion of X70 pipeline steel in thin electrolyte layer under disbonded coating by scanning Kelvin probe. Corros. Sci. 2009, 51, 186-190. [CrossRef]

8. Quej-Ake, L.M.; Galván-Martinez, R.; Contreras, A. Electrochemical and tension tests behavior of API 5L X60 pipeline steel in a simulated soil solution. Mater. Sci. Forum 2013, 755, 153-161.

9. Quej-Ake, L.M.; Mireles, M.J.; Galván-Martínez, R.; Contreras, A. Electrochemical characterization of X60 steel exposed to different soils from South of México. In Materials Characterization; Pérez-Campos, R., Contreras-Cuevas, A., Esparza-Muñoz, R., Eds.; Springer International Publishing: Cham, Switzerland, 2014; pp. 101-116.

10. Quej-Ake, L.M.; Nava, N.; Espinosa-Medina, M.A.; Liu, H.B.; Alamilla, J.L.; Sosa, E. Characterisation of soil/pipe interface at a pipeline failure after 36 years of service under impressed current cathodic protection. Corros. Eng. Sci. Technol. 2015, 50, 311-319. [CrossRef]

11. Quej, L.M.; Marín-Cruz, J.; Contreras, A. Electrochemical study of the corrosion rate of API steels in clay soils. Anti-Corros. Methods Mater. 2017, 64, 61-68. [CrossRef]

12. Quej-Ake, L.M.; Contreras, A.; Aburto, J. The effect of non-ionic surfactant on the internal corrosion for X52 steel in extra-heavy crude oil-in-water emulsions. Anti-Corros. Methods Mater. 2018, 65, 234-248. [CrossRef] 
13. Quej-Ake, L.M.; Contreras, A.; Liu, H.B.; Alamilla, J.L.; Sosa, E. The effect of the hydrodynamic and temperature on corrosion rate of API steels exposed to oilfield produced water. Anti-Corros. Methods Mater. 2019, 66, 101-114. [CrossRef]

14. Liu, Z.Y.; Li, X.G.; Cheng, Y.F. Electrochemical state conversion model for occurrence of pitting corrosion on a cathodically polarized carbon steel in a near-neutral pH solution. Electrochim. Acta 2011, 56, 4167-4175. [CrossRef]

15. Zhang, J.; Liu, F.; Hu, Q.; Huang, F.; Cheng, Z.Y.; Guo, J.T. The influence of tensile stress on the electrochemical behavior of X80 steel in a simulated acid soil solution. Anti-Corros. Methods Mater. 2015, 62, 103-108. [CrossRef]

16. Zhang, G.A.; Cheng, Y.F. Micro-electrochemical characterization of corrosion of pre-cracked X70 pipeline steel in a concentrated carbonate/bicarbonate solution. Corros. Sci. 2010, 52, 960-968. [CrossRef]

17. Yan, M.; Sun, C.; Xu, J.; Wu, T.; Yang, S.; Ke, W. Stress corrosion of pipeline steel under occluded coating disbondment in a red soil environment. Corros. Sci. 2015, 93, 27-38. [CrossRef]

18. Liu, Z.Y.; Li, X.G.; Du, D.W.; Zhai, G.L.; Cheng, Y.F. Stress corrosion cracking behavior of X70 pipe steel in an acidic soil environment. Corros. Sci. 2008, 50, 2251-2257. [CrossRef]

19. Szklarska-Smialowska, Z.; Xia, Z.; Rebak, R.B. Stress Corrosion Cracking of X-52 Carbon Steel in Dilute Aqueous Solutions. Corrosion 1994, 50, 335-338. [CrossRef]

20. Jiang, Q.T.; Zheng, K.; Li, X.G.; Li, Y.J.; Ma, M.L.; Shi, G.L.; Yuan, J.W. Atmospheric corrosion of Mg-rare earth alloy in typical inland and marine environments. Corros. Eng. Sci. Technol. 2014, 49, 651-655. [CrossRef]

21. Wang, J.Q.; Atrens, A. SCC initiation for X65 pipeline steel in the "high" pH carbonate/bicarbonate solution. Corros. Sci. 2003, 45, 2199-2217. [CrossRef]

22. Sánchez, J.; Fullea, J.; Andrade, C.; Alonzo, C. Stress corrosion cracking mechanism of prestressing steels in bicarbonate solutions. Corros. Sci. 2007, 49, 4069-4080. [CrossRef]

23. Wu, T.; Xu, J.; Sun, C.; Yan, M.; Yu, C.; Ke, W. Microbiological corrosion of pipeline steel under yield stress in soil environment. Corros. Sci. 2014, 88, 291-305. [CrossRef]

24. Chen, X.; Wang, G.; Gao, F.; Wang, Y.; He, C. Effects of sulphate-reducing bacteria on crevice corrosion in X70 pipeline steel under disbonded coatings. Corros. Sci. 2015, 101, 1-11. [CrossRef]

25. Cole, I.S.; Marney, D. The science of pipe corrosion: A review of the literature on the corrosion of ferrous metals in soils. Corros. Sci. 2012, 56, 5-16. [CrossRef]

26. Parker, M.E.; Peattie, E.G. Pipeline Corrosion and Cathodic protection: A Practical Manual for Corrosion Engineers Technicians, and Field Personnel, 3rd ed.; Gulf Professional Publishing: Houston, TX, USA, 1999; pp. 125-135.

27. Malik, H. Effect of $\mathrm{pH}$ on the corrosion inhibition of mild steel in $\mathrm{CO}_{2}$ saturated brine solution. Anti-Corros. Methods Mater. 2000, 47, 88-89. [CrossRef]

28. Fang, Z.; Wu, Y.S.; Zhang, L.; Li, J.Q. Application of the Modified Electrochemical Potentiodynamic Reactivation Method to Evaluate Intergranular Corrosion Susceptibility of Stainless Steels. Corrosion 1998, 54, 339-346. [CrossRef]

29. Jin, P.; Robbins, W.; Bota, G. Mechanism of magnetite formation in high temperature corrosion by model naphthenic acids. Corros. Sci. 2016, 111, 822-834. [CrossRef]

30. Mendoza, J.; Marín, J. Corrosion Behavior of Titanium and Nickel-based Alloys in $\mathrm{HCl}$ and $\mathrm{HCl}+\mathrm{H}_{2} \mathrm{~S}$ Environments. Int. J. Electrochem. Sci. 2008, 3, 346-355.

31. Flis-Kabulska, I.; Zakroczymski, T.; Flis, J. Accelerated entry of hydrogen into iron from $\mathrm{NaOH}$ solutions at low cathodic and low anodic polarisations. Electrochim. Acta 2007, 52, 2966-2977. [CrossRef]

32. Bosch, R.W. Electrochemical impedance spectroscopy for the detection of stress corrosion cracks in aqueous corrosion systems at ambient and high temperature. Corros. Sci. 2005, 47, 125-143. [CrossRef]

33. Little, B.; Ray, R. A perspective on corrosion inhibition by biofilms. Corrosion 2002, 58, 424-428. [CrossRef]

34. Pérez, N. Electrochemistry and Corrosion Science, 1st ed.; Kluwer Academic Publishers: Boston, MA, USA, 2004; pp. 1-26.

35. Marcus, P. Corrosion Mechanisms in Theory and Practice, 1st ed.; Marcel Dekker, Inc.: New York, NY, USA, 2002; pp. 1-17.

36. Wang, L.W.; Liu, Z.Y.; Cui, Z.Y.; Du, C.W.; Wang, X.H.; Li, X.G. In situ corrosion characterization of simulated weld heat affected zone on API X80 pipeline steel. Corros. Sci. 2014, 85, 401-410. [CrossRef]

37. Mohammadi, F.; Eliyan, F.F.; Alfantazi, A. Corrosion of simulated weld HAZ of API X-80 pipeline steel. Corros. Sci. 2012, 63, 323-333. [CrossRef] 
38. Zhou, C.; Huang, Q.; Guo, Q.; Zheng, J.; Chen, X. Sulphide stress cracking behaviour of the dissimilar metal welded joint of X60 pipeline steel and Inconel 625 alloy. Corros. Sci. 2016, 110, 242-252. [CrossRef]

39. Lu, B.T.; Chen, Z.K.; Lou, J.L. Pitting and stress corrosion cracking behavior in welded austenitic stainless steel. Electrochim. Acta 2005, 50, 1391-1403. [CrossRef]

40. ASME Code for Pressure Piping, B31.4. Pipeline Transportation Systems for Liquids and Slurries; American National Standard: New York, NY, USA, 2016.

41. ASME Code for Pressure Piping, B31.8. Gas Transmission and Distribution Piping Systems; American National Standard: New York, NY, USA, 2016.

42. Kuhn, H.A. Overview of mechanical properties and testing for design. In ASM Handbook-Mechanical Testing and Evaluation; Bailey, J.A., Barsom, J., Blau, P., Budinski, K., Bulsara, V., Carlsson, L., Carroll, N., Chandrasekar, S., Dadras, P., Eds.; ASM International: Ohio, OH, USA, 2000; Volume 8, pp. 120-172.

43. Bard, A.J.; Faulkner, L.R. Electrochemical Methods Fundamentals and Applications, 2nd ed.; John Wiley and Sons, Inc.: New York, NY, USA, 2001; pp. 1-43.

44. NACE Standard TM0198. Slow Strain Rate Test Method for Screening Corrosion-Resistant Alloys for Stress Corrosion Cracking in Sour Oilfield Service; NACE International: Houston, TX, USA, 2016.

45. Afanasyev, A.V.; Mel'nikov, A.A.; Konovalov, S.V.; Vaskov, M.I. The Analysis of the Influence of Various Factors on the Development of Stress Corrosion Defects in the Main Gas Pipeline Walls in the Conditions of the European Part of the Russian Federation. Int. J. Corros. 2018, 4, 1-10. [CrossRef]

46. NACE Standard Task Group 039. In-Line Nondestructive Inspection of Pipelines; NACE International: Houston, TX, USA, 2000.

47. Noyan, I.C.; Cohen, J.B. Residual Stresses, 1st ed.; Springer: New York, NY, USA, 1987; pp. $13-46$.

48. Oliver, W.C.; Pharr, G.M. An improved technique for determining hardness and elastic modulus using load and displacement sensing identation experiments. J. Mater. Res. 1992, 7, 1564-1583. [CrossRef]

49. Osman, T.M.; Rigney, J.D. Introduction to the mechanical behaviour of metals. In Mechanical Testing and Evaluation; Kuhn, H., Medlin, D., Eds.; ASM International: Materials Park, OH, USA, 2000; pp. 20-23.

50. De Araujo-Freitas, V.L.; de Albuquerque, V.H.C.; de Macedo Silva, E.; Almeida Silva, A.; Tavares, J.M.R.S. Nondestructive characterization of microstructures and determination of elastic properties in plain carbon steel using ultrasonic measurements. Mater. Sci. Eng. A 2010, 527, 4431-4437. [CrossRef]

51. Klein, P.A.; Hays, R.A.; Moran, P.J.; Scully, J.R. Hydrogen cracking initiation of a high-strength steel weldment. In Slow Strain Rate Testing for the Evaluation of Environmentally Induced Cracking: Research and Engineering Applications, ASTM STP 1210; Kane, R.D., Ed.; American Society for Testing and Materials: Philadelphia, PA, USA, 1993; pp. 202-222.

52. Schwartz, A.J.; King, W.E. The potential engineering of grain boundaries through thermomechanical processing. JOM 1998, 2, 50-55. [CrossRef]

53. ASTM G129. Standard Test Method for Slow Strain Rate Testing to Evaluate the Susceptibility of Metallic Materials to Environmentally Assisted Cracking; ASTM International: West Conshohocken, PA, USA, 2013.

54. National Energy Board (NEB). Public Inquiry Concerning Stress Corrosion Cracking on Canadian Oil and Gas Pipelines; Report of the Inquiry, MH-2-95; Regulatory Support Office: Calgary, AB, Canada, 1996.

55. Ugiansky, G.M.; Payer, J.H. Stress Corrosion Cracking-The Slow Strain Rate Technique; ASTM STP665; American Society for Testing and Materials: Philadelphia, PA, USA, 1979; pp. 1-236.

56. Kane, R.D.; Joia, C.J.B.M.; Small, A.L.L.T. Rapid screening of stainless steels for environmental cracking. Mater. Perform. 1997, 36, 71-74.

57. Salazar, M.; Espinosa, M.A.; Hernández, P.; Contreras, A. Evaluation of SCC susceptibility of supermartensitic stainless steel using slow strain rate tests. Corros. Eng. Sci. Technol. 2011, 46, 464-470. [CrossRef]

58. ISO 7539-7. Corrosion of Metals and Alloys—Stress Corrosion Testing-Part 7: Slow Strain Rate Testing; ISO International: Geneva, Switzerland, 2005.

59. Contreras, A.; Quej-Ake, L.M.; Lizárraga, C.R.; Pérez, T. The Role of Calcareous Soils in SCC of X52 Pipeline Steel. Mater. Res. Soc. Symp. Proc. 2015, 1756, 95-106. [CrossRef]

60. Lizárraga, C.R.; Pérez, T.; Galván-Martinez, R.; Quej-Aké, L.M.; Contreras, A. Stress corrosion cracking assessment of X52 pipeline steel exposed to Mexican soils. Mater. Technol. 2019, 53, 81-86. [CrossRef]

61. ANSI/NACE Standard TM0177. Laboratory Testing of Metals for Resistance to Sulfide Stress Cracking and Stress Corrosion Cracking in $\mathrm{H}_{2} \mathrm{~S}$ Environments; NACE International: Houston, TX, USA, 2016. 
62. Hyo-Sun, Y.; Evi-Gyun, N.; Se-Hi, C. Assessment of stress corrosion cracking susceptibility by a small punch test. Fatigue Fract. Eng. Mater. Struct. 2002, 22, 889-896.

63. Bruchhausen, M.; Altstadt, E.; Austin, T.; Dymacek, P.; Holmström, S.; Jeffs, S.; Lacalle, R.; Lancaster, R.; Matocha, K.; Petzova, J. European standard on small punch testing of metallic materials. Ubiquity Proc. 2018, 1, 11-21. [CrossRef]

64. Velázquez, Z.; Guzmán, E.; Espinosa, M.A. Contreras, Stress corrosion cracking behavior of X60 pipe steel in soil environment. A. Mater. Res. Soc. Symp. Proc. 2010, 1242, 69-78.

65. Contreras, A.; Salazar, M.; Albiter, A.; Galván, R.; Vega, O. Assessment of Stress Corrosion Cracking on Pipeline Steels Weldments Used in the Petroleum Industry by Slow Strain Rate Tests. In Arc Welding; Sudnik, W., Ed.; IntechOpen: Zagreb, Croatia, 2011; pp. 127-151.

66. Kane, R.D.; Wilhelm, S.M. Status of standardization activities on slow strain rate testing techniques. In Slow Strain Rate Testing for the Evaluation of Environmentally Induced Cracking: Research and Engineering Applications, ASTM STP 1210; Kane, R.D., Ed.; American Society for Testing and Materials: Philadelphia, PA, USA, 1993; pp. $40-47$.

67. ASTM G49. Standard Practice for Preparation and Use of Direct Tension Stress-Corrosion Test Specimens; ASTM International: West Conshohocken, PA, USA, 2011.

68. NACE Standard MR0103. Materials Resistant to Sulfide Stress Cracking in Corrosive Petroleum Refining Environments; NACE International: Houston, TX, USA, 2015.

69. NACE Standard TM0169. Laboratory Corrosion Testing of Metals; NACE International: Houston, TX, USA, 2012.

70. ASTM G38. Standard Practice for Making and Using C-Ring Stress-Corrosion Test Specimens; ASTM International: West Conshohocken, PA, USA, 2013.

71. ASTM G30. Standard Practice for Making and Using U-Bend Stress-Corrosion Test Specimen; ASTM International: West Conshohocken, PA, USA, 2016.

72. ASTM G58. Standard Practice for Preparation of Stress-Corrosion Test Specimen for Weldments; ASTM International: West Conshohocken, PA, USA, 2015.

73. ASTM G39. Standard Practice for Preparation and Use of Bend-Bend Stress-Corrosion Test Specimens; ASTM International: West Conshohocken, PA, USA, 2016.

74. NACE Standard TM0284. Evaluation of Pipeline and Pressure Vessel Steels for Resistance to Hydrogen-Induced Cracking; NACE International: Houston, TX, USA, 2016.

75. Beavers, J.A.; Koch, G.H. Limitations of the slow strain rate test technique. In Slow Strain Rate Testing for the Evaluation of Environmentally Induced Cracking: Research and Engineering Applications, ASTM STP1210; Kane, R.D., Ed.; American Society for Testing and Materials: Philadelphia, PA, USA, 1993; pp. 22-39.

76. Khayat, K.H.; Omran, A.F.; Neji, S.; Billberg, P.H.; Yahia, A. Test methods to evaluate form pressure of SCC. In Proceedings of the 3rd North American Conference on the Design and Use of Self-Consolidating Concrete (SCC 2008), Chicago, IL, USA, 10-12 November 2008; Shah, S.P., Ed.; Formwork Pressure: Chicago, IL, USA, 2008; pp. 308-314.

77. ASTM F519. Standard Test Method for Mechanical Hydrogen Embrittlement Evaluation of Plating Process and Service Environments; ASTM International: West Conshohocken, PA, USA, 2018.

78. ASTM G3. Standard Practice for Convention Applicable to Electrochemical Measurements in Corrosion Testing; ASTM International: West Conshohocken, PA, USA, 2019.

79. ASTM G106. Standard Practice for Verification of Algorithm and Equipment for Electrochemical Impedance Measurements; ASTM International: West Conshohocken, PA, USA, 2015.

80. ASTM G59. Standard Test Method for Conducting Potentiodynamic Polarization Resistance Measurements; ASTM International: West Conshohocken, PA, USA, 2014.

81. ASTM G57. Standard Test Method for Field Measurement of Soil Resistivity Using the Wenner Four-Electrode Method; ASTM International: West Conshohocken, PA, USA, 2012.

82. ASTM G187. Standard Test Method for Measurement of Soil Resistivity Using the Two-Electrode Soil Box Method; ASTM International: West Conshohocken, PA, USA, 2018.

83. ASTM D4959. Standard Test Method for Determination of Water Content of Soil by Direct Heating; ASTM International: West Conshohocken, PA, USA, 2016.

84. ASTM D4643. Standard Test Method for Determination of Water (Moisture) Content of Soil and Rock by Microwave Oven Heating; ASTM International: West Conshohocken, PA, USA, 2017. 
85. ASTM G51. Standard Test Method for Measuring $p H$ of Soil for Use in Corrosion Testing; ASTM International: West Conshohocken, PA, USA, 2018.

86. ASTM G200. Standard Test Method for Measurement of Oxidation-Reduction Potential (ORP) of Soil; ASTM International: West Conshohocken, PA, USA, 2014.

87. ASTM D4327. Standard Test Method for Anions in Water by Chemically Suppressed Ion Chromatography; ASTM International: West Conshohocken, PA, USA, 2017.

88. ASTM G8. Standard Test Methods for Cathodic Disbonding of Pipeline Coatings; ASTM International: West Conshohocken, PA, USA, 2019.

89. ASTM G42. Standard Test Method for Cathodic Disbonding of Pipeline Coatings Subjected to Elevated Temperatures; ASTM International: West Conshohocken, PA, USA, 2019.

90. ASTM G80. Standard Test Method for Specific Cathodic Disbonding of Pipeline Coatings; ASTM International: West Conshohocken, PA, USA, 2007.

91. ASTM G95. Standard Test Method for Cathodic Disbondment Test of Pipeline Coatings (Attached Cell Method); ASTM International: West Conshohocken, PA, USA, 2013.

92. NACE Standard TM0497. Measurement Techniques Related to Criteria for Cathodic Protection on Underground or Submerged Metallic Piping Systems; NACE International: Houston, TX, USA, 2018.

93. ASTM G62. Standard Test Method for Holiday Detection in Pipeline Coatings; ASTM International: West Conshohocken, PA, USA, 2014.

94. NACE Standard TM0106. Detection, Testing, and Evaluation of Microbiologically Influenced Corrosion (MIC) on External Surfaces of Buried Pipelines; NACE International: Houston, TX, USA, 2016.

95. ANSI/NACE Standard RP0502. Pipeline External Corrosion Direct Assessment Methodology; NACE International: Houston, TX, USA, 2002.

96. NACE Standard SP0206. Internal Corrosion Direct Assessment Methodology for Pipelines Carrying Normally Dry Natural Gas (DG-ICDA); NACE International: Houston, TX, USA, 2016.

97. NACE Standard SP0110. Wet Gas Internal Corrosion Direct Assessment Methodology for Pipelines; NACE International: Houston, TX, USA, 2018.

98. EPA 6010C. Inductively Coupled Plasma-Atomic Emission Spectrometry (ICP-AES); Environment Protection Agency: Washington, DC, USA, 2000.

99. ASTM D4294. Standard Test Method for Sulfur in Petroleum Products by Energy Dispersive X-Ray Fluorescence Spectrometry; ASTM International: West Conshohocken, PA, USA, 2016.

100. ASTM D287. Standard Test Method for API Gravity of Crude Petroleum and Petroleum Products (Hydrometer Method); ASTM International: West Conshohocken, PA, USA, 2012.

101. ASTM D1298. Standard Test Method for Density, Relative Density (Specific Gravity), or API Gravity of Crude Petroleum and Liquid Petroleum Products by Hydrometer Method; ASTM International: West Conshohocken, PA, USA, 2017.

102. ASTM D664. Standard Test Method for Acid Number of Petroleum Products by Potentiometric Titration; ASTM International: West Conshohocken, PA, USA, 2018.

103. ASTM D88. Standard Test Method for Saybolt Viscosity; ASTM International: West Conshohocken, PA, USA, 2019.

104. ASTM D1247. Standard Test Method for Density and Relative Density (Specific Gravity) of Liquids by Bingham Pycnometer; ASTM International: West Conshohocken, PA, USA, 2007.

105. ASTM D5002. Standard Test Method for Density, Relative Density, and API Gravity of Crude Oils by Digital Density Analyzer; ASTM International: West Conshohocken, PA, USA, 2019.

106. ASTM D4007. Standard Test Method for Water and Sediment in Crude Oil by the Centrifuge Method (Laboratory Procedure); ASTM International: West Conshohocken, PA, USA, 2016.

107. ASTM D1293. Standard Test Methods for $p H$ of Water; ASTM International: West Conshohocken, PA, USA, 2018.

108. ASTM E70. Standard Test Method for $\mathrm{pH}$ of Aqueous Solutions with the Glass Electrode; ASTM International: West Conshohocken, PA, USA, 2015.

109. ASTM D4006. Standard Test Method for Water in Crude Oil by Distillation; ASTM International: West Conshohocken, PA, USA, 2016.

110. ASTM D5863. Standard Test Methods for Determination of Nickel, Vanadium, Iron, and Sodium in Crude Oils and Residual Fuels by Flame Atomic Absorption Spectrometry; ASTM International: West Conshohocken, PA, USA, 2016. 
111. ASTM D512. Standard Test Methods for Chloride Ion in Water; ASTM International: West Conshohocken, PA, USA, 2012.

112. ASTM D516. Standard Test Method for Sulfate Ion in Water; ASTM International: West Conshohocken, PA, USA, 2016.

113. ASTM D1125. Standard Test Methods for Electrical Conductivity and Resistivity of Water; ASTM International: West Conshohocken, PA, USA, 2014.

114. ASTM D1068. Standard Test Methods for Iron in Water; ASTM International: West Conshohocken, PA, USA, 2015.

115. ASTM F1094. Standard Test Methods for Microbiological Monitoring of Water Used for Processing Electron and Microelectronic Devices by Direct Pressure Tap Sampling Valve and by the Presterilized Plastic Bag Method; ASTM International: West Conshohocken, PA, USA, 2012.

116. NACE International Publication 31205, Selection. Application, and Evaluation of Biocides in the Oil and Gas Industry; NACE International: Houston, TX, USA, 2006.

117. Canadian Energy Pipeline Association (CEPA). An industry leading document detailing the management of transgranular SCC. In Stress Corrosion Cracking, Recommended Practices, 2nd ed.; CEPA: Calgary, AB, Canada, 2007.

118. Fürstner, R.; Barthlott, W.; Neinhuis, C.; Walzel, P. Wetting and self-Cleaningproperties of artificial superhydrophobic surfaces. Langmuir 2005, 21, 956-961. [CrossRef] [PubMed]

119. Bellido, D.A.; Zheng, S.; Zhang, X.; Huang, Y.; Zeng, X.; Zhang, Q.; Chen, Z. Solvent-Free Synthesis and Hydrophobization of Biobased Epoxy Coatings for Anti-Icing and Anticorrosion Applications. ACS Sustain. Chem. Eng. 2019, 7, 19131-19141. [CrossRef]

120. NACE Standard SP0394. Application, Performance, and Quality Control of Plant-Applied Single Layer Fusion-Bonded Epoxy External Pipe Coating; NACE International: Houston, TX, USA, 2013.

121. NACE Standard RP0375. Field-Applied Underground Wax Coating Systems for Underground Pipelines: Application, Performance, and Quality Control; NACE International: Houston, TX, USA, 2018.

122. NACE Standard RP0185. Extruded Polyolefin Resin Coating Systems with Soft Adhesives for Underground or Submerged Pipe; NACE International: Houston, TX, USA, 2007.

123. NACE Standard RP0399. Plant-Applied External Coal Tar Enamel Pipe Coating Systems: Application, Performance, and Quality Control; NACE International: Houston, TX, USA, 2004.

124. Maocheng, Y.; Jin, X.; Libao, Y.; Tangqing, W.U.; Cheng, S.; Wei, K. EIS analysis on stress corrosion initiation of pipeline steel under disbonded coating in near-neutral $\mathrm{pH}$ simulated soil electrolyte. Corros. Sci. 2016, 110, 23-34. [CrossRef]

125. NACE SP0169. External Corrosion Control in Underground or Submerged Pipelines; NACE International: Houston, TX, USA, 2013.

126. Leis, B.N.; Eiber, R.J. Stress-Corrosion Cracking On Gas-Transmission Pipelines: History, Causes, and Mitigation, Proceedings of First International Business Conference on Onshore Pipelines. In Proceedings of the First International Business Conference on Onshore Pipelines, Berlin, Germany, 8-9 December 1997; IBCOP: Berlin, Germany, 1997; pp. 1-17.

127. Sawamura, M.; Asahi, H.; Omura, T.; Kishikawa, H.; Ishikawa, N.; Kimura, M. Near Neutral pH SCC Properties of Pipeline Steels of Grade X80 and X52. In Proceedings of the Corrosion/11, Houston, TX, USA, 13-17 March 2011; Paper No. 11286; NACE International: Houston, TX, USA, 2011.

128. Asahi, H.; Kushida, T.; Kimura, M.; Fukai, H.; Okano, S. Role of Microstructures on Stress Corrosion Cracking of Pipeline Steels in Carbonate-Bicarbonate Solution. Corrosion 1999, 55, 644-652. [CrossRef]

129. González-Rodriguez, J.G.; Casales, M.; Salinas-Bravo, V.M.; Albarran, J.L.; Martinez, L. Effect of Microstructure on the Stress Corrosion Cracking of X-80 Pipeline Steel in Diluted Sodium Bicarbonate Solutions. Corrosion 2002, 58, 584-590. [CrossRef]

130. Kushida, T.; Nose, K.; Asahi, H.; Kimura, M.; Yamane, Y.; Endo, S.; Kawano, H. Effects of Metallurgical Factors and Test Conditions on Near Neutral pH SCC of Pipeline Steels. In Proceedings of the Corrosion/01, Houston, TX, USA, 11-16 March 2001; Paper No. 01213. NACE International: Houston, TX, USA, 2001.

131. Bulger, J.; Luo, J. Effect of microstructure on near-neutral pH SCC. In Proceedings of the 20003 rd International Pipeline Conference, Calgary, AB, Canada, 1-5 October 2000; ASME: Calgary, AB, Canada, 2000. [CrossRef] 
132. Contreras, A.; Hernández, S.L.; Orozco-Cruz, R.; Galvan-Martinez, R. Mechanical and environmental effects on stress corrosion cracking of low carbon pipeline steel in a soil solution. Mater. Des. 2012, 35, 281-289. [CrossRef]

133. Liu, Z.Y.; Li, X.G.; Du, C.W.; Lu, L.; Zhang, Y.R.; Cheng, Y.F. Effect of inclusions on initiation of stress corrosion cracks in X70 pipeline steel in an acidic soil environment. Corros. Sci. 2009, 51, 895-900. [CrossRef]

134. Al-Mansour, M.; Alfantazi, A.M.; Elboujdaini, M. Sulfide stress cracking resistance of API-X100 high strength low alloy steel. Mater. Des. 2009, 30, 4088-4094. [CrossRef]

135. Kong, D.J.; Wu, Y.Z.; Long, D. Stress corrosion of X80 pipeline steel welded joints by slow strain test in NACE $\mathrm{H}_{2} \mathrm{~S}$ solutions. J. Iron Steel Res. Int. 2013, 20, 40-46. [CrossRef]

136. Contreras, A.; Albiter, A.; Salazar, M.; Pérez, R. Slow strain rate corrosion and fracture characteristics of X-52 and X-70 pipeline steels. Mater. Sci. Eng. A 2005, 407, 45-52. [CrossRef]

137. Vega, O.E.; Villagómez, A.; Hallen, J.M.; Contreras, A. Sulphide stress corrosion cracking of multiple welding repairs of girth welds in line pipe. Corros. Eng. Sci. Technol. 2009, 44, 289-296. [CrossRef]

138. Carneiro, R.A.; Ratnapuli, R.C.; de Freitas Cunha Lins, V. The influence of chemical composition and microstructure of API linepipe steels on hydrogen induced cracking and sulfide stress corrosion cracking. Mater. Sci. Eng. A 2003, 357, 104-110. [CrossRef]

139. Shigeru, E.; Moriyasu, N.; Yasuo, K.; Kazuyoshi, U. Sulfide stress corrosion cracking in welded joints of welded linepipes. ISIJ Int. 1994, 34, 217-223.

140. NACE Standard MR0175/ISO 15156. Petroleum and Natural Gas Industries-Materials for Use in $\mathrm{H}_{2}$ S-Containing Environments in Oil and Gas Production; NACE International: Houston, TX, USA, 2015.

141. Gu, B.; Yu, W.Z.; Luo, J.L.; Mao, X. Transgranular Stress Corrosion Cracking of X-80 and X-52 Pipeline Steels in Dilute Aqueous Solution with Near-Neutral pH. Corrosion 1999, 55, 312-318. [CrossRef]

142. Beavers, J.A.; Harle, B.A. Mechanisms of High-pH and Near-neutral-pH SCC of Underground Pipelines. J. Offshore Mech. Arctic Eng. Trans. ASME 2001, 123, 147-151. [CrossRef]

143. Arafin, M.A.; Szpunar, J.A. Effect of bainitic microstructure on the susceptibility of pipeline steels to hydrogen induced cracking. Mater. Sci. Eng. A 2001, 528, 4927-4940. [CrossRef]

144. Omura, T.; Amaya, H.; Asahi, H.; Sawamura, M.; Kimura, M. Near neutral SCC properties of grade X80 linepipe. In Proceedings of the Corrosion/09, Atlanta, GA, USA, 22-26 March 2009; paper no. 09092; NACE International: Houston, TX, USA, 2009.

145. Parkins, R.N. Mechanism of Stress-Corrosion Cracking. Corrosion 1994, 1, 3-31.

146. Parkins, R.N. Stress Corrosion Cracking. In Uhlig's Corrosion Handbook; Revie, R.W., Ed.; John Wiley and Sons, INC: Ottawa, ON, Canada, 2000; pp. 191-203.

147. Elboujdaini, M.; Wang, Y.Z.; Revie, R.W. Initiation of stress corrosion cracking on X-65 linepipe steels in near-neutral pH environment. In Proceedings of the 2000 3rd International Pipeline Conference, Calgary, AB, Canada, 1-5 October 2000; ASME: Calgary, AB, Canada, 2000. [CrossRef]

148. Pan, B.W.; Peng, X.; Chu, W.Y.; Su, Y.J.; Qiao, L.J. Stress corrosion cracking of API X-60 pipeline in a soil containing water. Mater. Sci. Eng. A 2006, 434, 76-81. [CrossRef]

149. Delanty, B.S.; O’Beirne, J. Major Field Study Compares Pipeline SCC with Coatings. Oil Gas J. 1992, 15, 39-44.

150. Fitzgerald, J.H. Evaluating Soil Corrosivity-Then and now. Mater. Perform. 1993, 32, 9-17.

151. Benmoussat, A.; Hadjel, M. Corrosion behaviour of low carbon line pipe steel in soil environment. J. Corros. Sci. Eng. 2005, 7, 1-14.

152. Fang, B.Y.; Atrens, A.; Wang, J.Q.; Han, E.H.; Zhu, Z.Y.; Ke, W. Review of stress corrosion cracking of pipeline steels in low and high pH solutions. J. Mater. Sci. 2003, 38, 127-132. [CrossRef]

153. Parkins, R.N.; Fessler, R.R. Stress corrosion cracking of high-pressure gas transmission pipelines. Mater. Eng. Appl. 1978, 1, 80-96. [CrossRef]

154. Fessler, R.R. Stress-corrosion cracking temperature effects. In Proceedings of the 6th American Gas Association symposium on line pipe research, Houston, TX, USA, 29 October 1979; Catalogue No. L30175; PRCI: Houston, TX, USA, 1979.

155. Wilmott, M.J.; Jack, T.R. Corrosion by soils. In Uhlig's Corrosion Handbook; John Wiley and Sons, Inc.: New York, NY, USA, 2000; pp. 333-349.

156. Jack, T.R.; Erno, B.; Krist, K.; Fessler, R.R. Generation of near neutral pH and high pH SCC environments on buried pipelines. In Proceedings of the Corrosion/00, Orlando, FL, USA, 26-31 March 2000; Paper No. 00362; NACE International: Houston, TX, USA, 2000. 
157. Parkins, R.N.; Blanchard, W.K.; Delanty, B.S. Transgranular stress corrosion cracking of high-pressure pipelines in contact with solutions of near neutral $\mathrm{pH}$. Corrosion 1994, 50, 394-408. [CrossRef]

158. NACE Standard SP0204. Stress Corrosion Cracking (SCC) Direct Assessment Methodology; NACE International: Houston, TX, USA, 2015.

159. Javidi, M.; Bahalaou-Horeh, S. Investigating the mechanism of stress corrosion cracking in near-neutral and high pH environments for API 5L X52 steel. Corros. Sci. 2014, 80, 213-220. [CrossRef]

160. Chu, R.; Chen, W.; Wang, S.H.; King, F.; Jack, T.R. Microstructure Dependence of Stress Corrosion Cracking Initiation in X-65 Pipeline Steel Exposed to a Near-Neutral pH Soil Environment. Corrosion 2004, 60, 275-283. [CrossRef]

161. Chen, W.; King, F.; Vokes, E. Characteristics of Near-Neutral-pH Stress Corrosion Cracks in an X-65 Pipeline. Corrosion 2002, 58, 267-275. [CrossRef]

162. Li, M.C.; Cheng, Y.F. Corrosion of the stressed pipe steel in carbonate-bicarbonate solution studied by scanning localized electrochemical impedance spectroscopy. Electrochim. Acta 2008, 53, 2831-2836. [CrossRef]

163. Liu, Z.Y.; Li, X.G.; Cheng, Y.F. Mechanistic aspect of near-neutral pH stress corrosion cracking of pipelines under cathodic polarization. Corros. Sci. 2012, 55, 54-60. [CrossRef]

164. Li, M.C.; Cheng, Y.F. Mechanistic investigation of hydrogen-enhanced anodic dissolution of X-70 pipe steel and its implication on near-neutral pH SCC of pipelines. Electrochim. Acta 2007, 52, 8111-8117. [CrossRef]

165. Oskuie, A.A.; Shahrabi, T.; Shahariari, A.; Saebnoori, E. Electrochemical impedance spectroscopy analysis of X70 pipeline steel stress corrosion cracking in high $\mathrm{pH}$ carbonate solution. Corros. Sci. 2012, 61, 111-122. [CrossRef]

166. Yin, Z.F.; Zhao, W.Z.; Feng, Y.R.; Zhu, S.D. Characterisation of $\mathrm{CO}_{2}$ corrosion scale in simulated solution with Cl- ion under turbulent flow conditions. Corros. Eng. Sci. Technol. 2009, 44, 453-461. [CrossRef]

167. Dong, C.F.; Fu, A.Q.; Li, X.G.; Cheng, Y.F. Localized EIS characterization of corrosion of steel at coating defect under cathodic protection. Corros. Sci. 2008, 54, 628-633. [CrossRef]

168. Romanoff, M. Underground Corrosion; National Bureau of Standards: Washington, DC, USA, 1957; pp. $168-178$.

169. Liao, K.; Yao, Q.; Wu, X.; Jia, W. A Numerical Corrosion Rate Prediction Method for Direct Assessment of Wet Gas Gathering Pipelines Internal Corrosion. Energies 2012, 5, 3892-3907. [CrossRef]

170. NACE Standard 3T199. Techniques for Monitoring Corrosion and Related Parameters in Field Applications; NACE International: Houston, TX, USA, 1999.

171. NACE Standard RP0775. Preparation, Installation, Analysis, and Interpretation of Corrosion Coupons in Oilfield Operations; NACE International: Houston, TX, USA, 2018.

172. NACE Standard RP0102. Standard Recommended Practice in-Line Inspection of Pipelines; NACE International: Houston, TX, USA, 2017.

173. Van-Boven, G.; Chen, W.; Rogge, R. The role of residual stress in neutral pH stress corrosion cracking of pipeline steels. Part I: Pitting and cracking occurrence. Acta Mater. 2007, 55, 29-42. [CrossRef]

174. Hoeppner, D.W. Model for prediction of fatigue lives based upon a pitting corrosion fatigue process. Fatigue Mech. ASTM STP 1979, 675, 841-870.

175. Fang, B.Y.; Eadie, R.L.; Chen, W.X.; Elboujdaini, M. Pit to crack transition in X-52 pipeline steel in near neutral $\mathrm{pH}$ environment Part 1 -Formation of blunt cracks from pits under cyclic loading. Corros. Eng. Sci. Technol. 2010, 45, 302-312. [CrossRef]

176. Kondo, Y. Prediction of fatigue crack initiation life based on pit growth. Corrosion 1989, 45, 7-11. [CrossRef]

177. Eslami, A. Near-neutral pH Stress Corrosion Crack Initiation under Simulated Coating Disbondment. Ph.D. Thesis, University of Alberta, Faculty of Graduate Studies and Research in Materials Engineering, Edmonton, AB, Canada, 2012.

178. Eslami, A.; Fang, B.; Kania, R.; Worthingham, B.; Been, J.; Eadie, R.; Chen, W. Stress corrosion cracking initiation under the disbonded coating of pipeline steel in near-neutral pH environment. Corros. Sci. 2010, 52, 3750-3756. [CrossRef]

179. Shi, P.; Mahadevan, S. Damage tolerance approach for probabilistic pitting corrosion fatigue life prediction. Eng. Fract. Mech. 2001, 68, 1493-1507. [CrossRef]

180. Alamilla, J.L.; Sosa, E.; Sánchez-Magaña, C.A.; Andrade-Valencia, R.; Contreras, A. Failure analysis and mechanical performance of an oil pipeline. Mater. Des. 2013, 50, 766-773. [CrossRef]

181. Song, F.M. Predicting the mechanisms and crack growth rates of pipelines undergoing stress corrosion cracking at high pH. Corros. Sci. 2009, 51, 2657-2674. [CrossRef] 
182. Kamaya, M.; Haruna, T. Crack initiation model for sensitized 304 stainless steel in high temperature water. Corros. Sci. 2006, 48, 2442-2456. [CrossRef]

183. Breton, T.; Sánchez-Gheno, J.C.; Alamilla, J.L.; Alvarez-Ramirez, J. Identification of failure type in corroded pipelines: A Bayesian probabilistic approach. J. Hazard Mater. 2010, 179, 628-634. [CrossRef]

184. Alamilla, J.L.; Sosa, E. Stochastic modelling of corrosion damage propagation in active sites from field inspection data. Corros. Sci. 2008, 50, 1811-1819. [CrossRef]

185. Alamilla, J.L.; Espinosa-Medina, M.A.; Sosa, E. Modelling steel corrosion damage in soil environment. Corros. Sci. 2009, 51, 2628-2638. [CrossRef]

186. Velázquez, J.C.; Caleyo, F.; Hallen, J.M.; Romero-Mercado, O.; Herrera-Hernández, H. Probabilistic Analysis of Different Methods Used to Compute the Failure Pressure of Corroded Steel Pipelines. Int. J. Electrochem. Sci. 2013, 8, 11356-11370.

187. Wang, Y.; Wharton, J.A.; Shenoi, R.A. Ultimate strength analysis of age steel-plated structures exposed to marine corrosion damage: A review. Corros. Sci. 2014, 86, 42-60. [CrossRef]

188. Mills, G.; Fones, G. Review of in situ methods and sensors for monitoring the marine environment. Sens. Rev. 2012, 32, 17-28. [CrossRef]

189. Galvele, J.R. Past, Present, and Future of Stress Corrosion Cracking. Corrosion 1999, 55, 723-731. [CrossRef]

190. Velázquez, J.C.; Van Der Weide, J.A.M.; Hernández, E. Statistical Modelling of Pitting Corrosion: Extrapolation of the Maximum Pit Depth-Growth. Int. J. Electrochem. Sci. 2014, 9, 4129-4143.

191. API 579-1/ASME FFS-1. Fitness for Service, American Petroleum Institute/The American Society of Mechanical Engineers; API/ASME: Washington, DC, USA, 2016.

192. BS 7910. Guide to Methods for Assessing the Acceptability of Flaws in Metallic Structures; BSI Standards Publication: London, UK, 2013.

193. Campbell, S.A.; Campbell, N.; Walsh, F.C. Developments in Marine Corrosion; RSC: Cambridge, UK, 1998; pp. 1-25.

194. Foroulis, Z.A. Role of solution $\mathrm{pH}$ on wet $\mathrm{H}_{2} \mathrm{~S}$ cracking in hydrogen production. Corros. Prev. Control 1993, 8 , $84-89$.

195. Bradford, S.A. Practical Handbook of Corrosion Control in Soils; Casti Publishing: Edmonton, AB, Canada, 2001; pp. 1-25.

196. Rabinowicz, E. Friction and Wear of Materials; John Wiley and Sons, Inc.: New York, NY, USA, 1966; pp. 1-30.

197. Borenstein, S.W. Microbiologically Influenced Corrosion Handbook; Woodhead Publishing Ltd.: New York, NY, USA, 1994; pp. 1-49.

198. Xu, L.Y.; Cheng, Y.F. An experimental investigation of corrosion of X100 pipeline steel under uniaxial elastic stress in a near-neutral pH solution. Corros. Sci. 2012, 59, 103-109. [CrossRef]

199. Wu, T.; Xu, J.; Yan, M.; Sun, C.; Yu, C.; Ke, W. Synergistic effect of sulfate-reducing bacteria and elastic stress on corrosion of X80 steel in soil solution. Corros. Sci. 2014, 83, 38-47. [CrossRef]

200. Wu, T.; Yan, M.; Xu, J.; Liu, Y.; Sun, C.; Ke, W. Mechano-chemical effect of pipeline steel in microbiological corrosion. Corros. Sci. 2016, 108, 160-168. [CrossRef]

201. Meng, G.Z.; Zhang, C.; Cheng, Y.F. Effects of corrosion product deposit on the subsequent cathodic and anodic reactions of X-70 steel in near-neutral pH solution. Corros. Sci. 2008, 50, 3116-3122. [CrossRef]

202. Zhu, M.; Du, C.; Li, X.; Liu, Z.; Li, H.; Zhang, D. Effect of AC on stress corrosion cracking behavior and mechanism of X80 pipeline steel in carbonate/bicarbonate solution. Corros. Sci. 2014, 87, 224-232. [CrossRef]

203. Stipaničev, M.; Rosas, O.; Basseguy, R.; Turcu, F. Electrochemical and fractographic analysis of Microbiologically Assisted Stress Corrosion Cracking of carbon steel. Corros. Sci. 2014, 80, 60-70. [CrossRef]

204. Stewart, P.S.; Costerton, J.W. Antibiotic resistance of bacteria in biofilms. Lancet 2001, 358, 135-138. [CrossRef]

205. Zapata-Peñasco, I.; Salazar-Coria, L.; Saucedo-García, M.; Villa-Tanaka, L.; Hernández-Rodríguez, C. Bisulfite reductase and nitrogenase genes retrieved from biocorrosive bacteria in saline produced waters of offshore oil recovery facilities. Int. Biodeterior. Biodegrad. 2013, 81, 17-27. [CrossRef]

206. Zapata-Peñasco, I.; Salazar-Coria, L.; Saucedo-García, M.; Villa-Tanaca, L.; Hernández-Rodríguez, C. Bisulfite reductase gene expression of thermophilic sulfate-reducing bacteria from saline connate water of oil reservoirs with high temperature. Int. Biodeterior. Biodegrad. 2016, 108, 198-206. [CrossRef]

207. Bhushan, B.; Gupta, B.K. Handbook of Tribology, Materials, Coatings, and Surface Treatments; Krieger Publishing Company: New York, NY, USA, 1997; pp. 1-25. 
208. Morales-Gil, P.; Negrón-Silva, G.; Romero-Romo, M.; Ángeles-Chávez, C.; Palomar-Pardavé, M. Corrosion inhibition of pipeline steel grade API 5L X52 immersed in a $1 \mathrm{M} \mathrm{H}_{2} \mathrm{SO}_{4}$ aqueous solution using heterocyclic organic molecules. Electrochim. Acta 2004, 49, 4733-4741. [CrossRef]

209. Flis, J.; Ziomek-Moroz, M. Effect of carbon on stress corrosion cracking and anodic oxidation of iron in $\mathrm{NaOH}$ solutions. Corros. Sci. 2008, 50, 1726-1733. [CrossRef]

210. Alvaro, A.; Olden, V.; Akselsen, O.M. 3D cohesive modelling of hydrogen embrittlement in the heat affected zone of an X70 pipeline steel. Int. J. Hydrog. Energy 2013, 38, 7539-7549. [CrossRef]

211. Koh, S.U.; Yang, B.Y.; Kim, K.Y. Effect of Alloying Elements on the Susceptibility to Sulfide Stress Cracking of Line Pipe Steels. Corrosion 2004, 60, 262-274. [CrossRef]

212. Charles, E.A.; Parkins, R.N. Generation of Stress Corrosion Cracking Environments at Pipeline Surfaces. Corrosion 1995, 51, 518-527. [CrossRef]

213. Goodman, L.R.; Singh, P.M. Repassivation behavior of X65 pipeline steel in fuel grade ethanol and its implications for the stress corrosion cracking mechanism. Corros. Sci. 2012, 65, 238-248. [CrossRef]

214. Eadie, R.L.; Szklarz, K.E.; Sutherby, R.L. Corrosion Fatigue and Near-Neutral pH Stress Corrosion Cracking of Pipeline Steel and the Effect of Hydrogen Sulfide. Corrosion 2005, 61, 167-173. [CrossRef]

215. Pessu, F.; Hua, Y.; Barker, R.; Neville, A. An investigation of the overall corrosion behavior of X65 (UNS K03014) carbon steel in different $\mathrm{H}_{2} \mathrm{~S}-\mathrm{CO}_{2}$-containing environments. In Proceedings of the Corrosion/16, Vancouver, BC, Canada, 6-10 March 2016; Paper No. 7643; NACE International: Houston, TX, USA, 2016.

216. Kentish, P. Stress corrosion cracking of gas pipelines-Effect of surface roughness, orientations and Xattening. Corros. Sci. 2007, 49, 2521-2533. [CrossRef]

217. Ashour, E.A.; Khorshed, L.A.; Youssef, G.I.; Zakria, H.M.; Khalifa, T.A. Electrochemical and Stress Corrosion Cracking Behavior of Alpha-Al Bronze in Sulfide-Polluted Salt Water: Effect of Environmentally-Friendly Additives. Mater. Sci. Appl. 2014, 5, 10-19. [CrossRef]

218. Horner, D.A.; Connolly, B.J.; Zhou, S.; Crocker, L.; Turnbull, A. Novel images of the evolution of stress corrosion cracks from corrosion pits. Corros. Sci. 2011, 53, 3466-3485. [CrossRef]

219. Zanotto, F.; Grassi, V.; Balbo, A.; Monticelli, C.; Zucchi, F. Stress corrosion cracking of LDX $2101^{\circledR}$ duplex stainless steel in chloride solutions in the presence of thiosulphate. Corros. Sci. 2014, 80, 205-212. [CrossRef]

220. Calabrese, L.; Bonaccorsi, L.; Galeano, M.; Proverbio, E.; Di Pietro, D.; Cappuccini, F. Identification of damage evolution during SCC on 17-4 PH stainless steel by combining electrochemical noise and acoustic emission techniques. Corros. Sci. 2015, 98, 573-584. [CrossRef]

221. Leban, M.; Bajt, Ž.; Legat, A. Detection and differentiation between cracking processes based on electrochemical and mechanical measurements. Electrochim. Acta 2004, 49, 2795-2801. [CrossRef]

222. Liu, Z.Y.; Li, X.G.; Du, C.W.; Cheng, Y.F. Local additional potential model for effect of strain rate on SCC of pipeline steel in an acidic soil solution. Corros. Sci. 2009, 51, 2863-2871. [CrossRef]

223. NACE Standard SP0116. Standard Practice Multiphase Flow Internal Corrosion Direct Assessment (MP-ICDA) Methodology for Pipelines; NACE International: Houston, TX, USA, 2016.

224. Mackintosh, D.D.; Atherton, D.L. Test rigs for magnetic flux leakage inspection tools for pipelines. Mater. Eval. 1992, 1, 13-17.

225. ASME B31G. Manual for Determining the Remaining Strength of Corroded Pipelines, ASME Code for Pressure Piping, B31; An American National Standard: New York, NY, USA, 2012.

226. Velázquez, J.C.; Caleyo, F.; Valor, A.; Venegas, V.; Espina-Hernández, J.H.; Hallen, J.M.; López, M.R. Study helps model buried pipeline pitting corrosion. Oil Gas J. 2009, 107, 64-73.

227. Caleyo, F.; Valor, A.; Alfonso, L.; Vidal, J.; Pérez-Baruch, E.; Hallen, J.M. Bayesian analysis of external corrosion data of non-piggable underground pipelines. Corros. Sci. 2015, 90, 33-45. [CrossRef]

228. Caleyo, F.; Velázquez, J.C.; Valor, A.; Hallen, J.M. Probability distribution of pitting corrosion depth and rate in underground pipelines: A Monte Carlo study. Corros. Sci. 2009, 51, 1925-1934. [CrossRef]

229. Velázquez, J.C.; Cruz-Ramirez, J.C.; Valor, A.; Venegas, V.; Caleyo, F.; Hallen, J.M. Modeling localized corrosion of pipeline steels in oilfield produced water environments. Eng. Fail. Anal. 2017, 79, $216-231$. [CrossRef]

230. Papavinasam, S.; Doiron, A.; Revie, R.W. Model to predict internal pitting corrosion of oil and gas pipelines. Corrosion 2010, 66, 035006-035006-11. [CrossRef]

231. Caleyo, F.; Alfonso, L.; Alcántara, J.; Hallen, J.M. On the estimation of failure rates of multiple pipeline systems. J. Press. Vessel. Technol. 2008, 130, 021704-1-021704-8. [CrossRef] 
232. Lagad, V.V.; Srinivasan, S.; Kane, R.D. Facilitating internal corrosion direct assessment using advanced flow and corrosion prediction models. In Proceedings of the Corrosion/08, New Orleans, LA, USA, 16-20 March 2008; Paper No. 08131; NACE International: Houston, TX, USA, 2008.

233. Henthorne, M. The slow strain rate stress corrosion cracking test-A 50 year retrospective. Corrosion 2016, 72, 1488-1518. [CrossRef]

Publisher's Note: MDPI stays neutral with regard to jurisdictional claims in published maps and institutional affiliations.

(C) 2020 by the authors. Licensee MDPI, Basel, Switzerland. This article is an open access article distributed under the terms and conditions of the Creative Commons Attribution (CC BY) license (http://creativecommons.org/licenses/by/4.0/). 